Perceived Realism and the CSI-Effect

\title{
PERCEIVED REALISM AND THE CSI-EFFECT
}

by

Jordan Monnink

A thesis submitted to the Faculty of Graduate and Postdoctoral Affairs in partial fulfillment of the requirements for the degree of

\author{
Master of Arts \\ in \\ Psychology \\ Carleton University, \\ Ottawa, Canada
}

(C)2015, Jordan Monnink 


\begin{abstract}
Anecdotal claims made by lawyers, judges, and legal scholars state that jurors are increasingly expecting the presence of DNA and other forensic evidence in criminal trials (Cole \& DiosoVilla, 2007, Tyler, 2006). Further, the presentation of this evidence is claimed to be a requisite for a jury to find a defendant guilty (Tyler, 2006). Some have speculated that this expectation has been created by the rise in the popularity of crime-drama television shows such as Crime Scene Investigation (CSI). This research extends what is known about what has been aptly termed the “CSI-Effect." Utilizing Cultivation Theory (Gerbner, 1976), this research examined whether juror ratings of guilt in a criminal trial are impacted by a relationship between the degree to which a juror believes television reflects real-life practices (perceived realism) and the presentation of different types of strong or weak evidence. Overall, those high in perceived realism were more likely to convict than those low in perceived realism. Further, perceived realism had no impact on jurors' expectation that DNA, or any particular type of evidence, be presented at trial. Additionally, eyewitness testimony significantly decreased jurors' likelihood of voting guilty. Finally, evidence strength only had an impact on verdict in the eyewitness condition, with strong evidence increasing jurors' likelihood of voting guilty. The results here suggest that perceived realism does not increase a jurors' expectation that DNA evidence be presented in court and thus does not support the CSI-effect. Rather, perceived realism may actually be a desirable trait for prosecutors, as jurors were more likely to convict, regardless of the evidence.
\end{abstract}




\section{ACKNOWLEDGEMENTS}

First and foremost, I would like to thank Dr. Evelyn Maeder. Your patience, understanding, and uncompromising support is the only way I could have gotten this far. I would also like to thank my lab mates Susan, Laura, Logan, Kris and Kendra. The wealth of knowledge they possess helped me out immensely so many times. 


\section{TABLE OF CONTENTS}

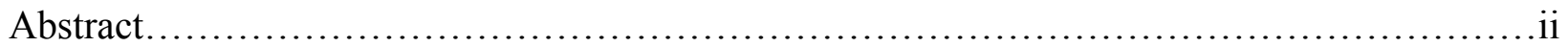

Acknowledgements................................................................ iii

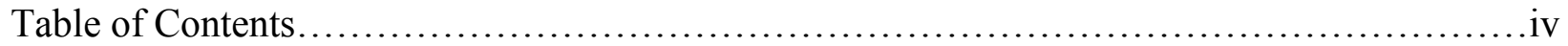

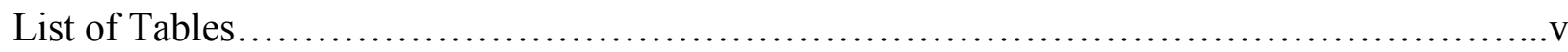

List of Appendices................................................................

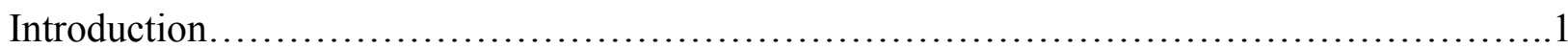

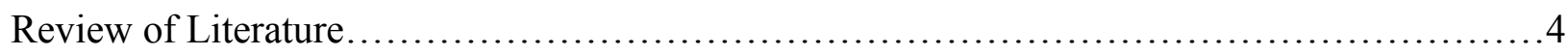

Perceptions of DNA Evidence................................................4

The CSI-Effect.......................................................... 11

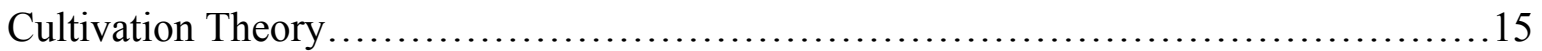

Perceived Realism...................................................... 18

The Current Study...................................................... 23

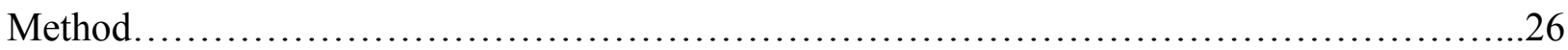

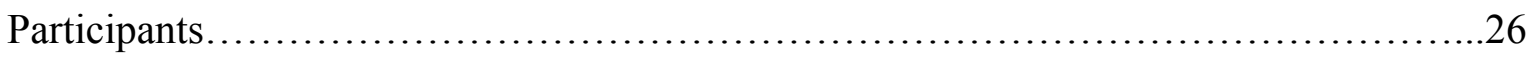

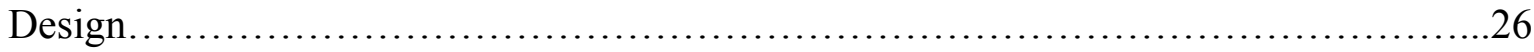

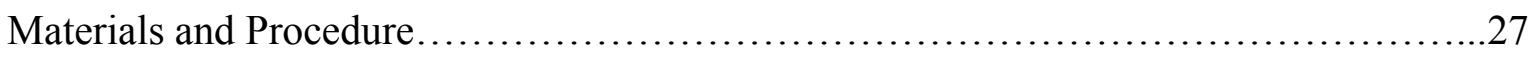

Measures.................................................................28

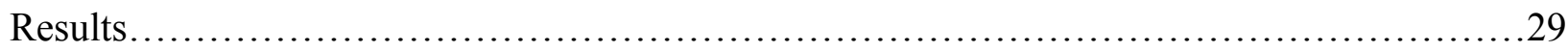

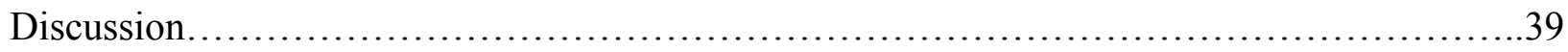

References.................................................................. 49

Appendices....................................................................55 


\section{LIST OF TABLES}

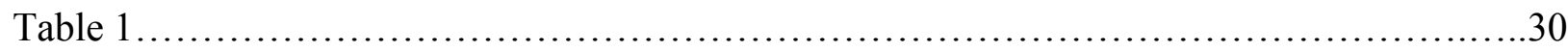

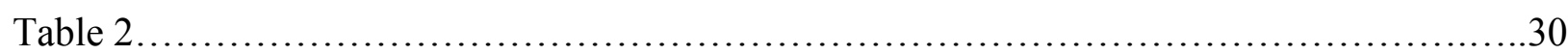

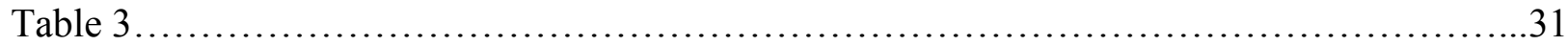

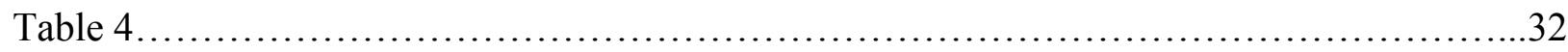

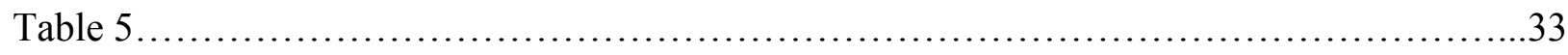

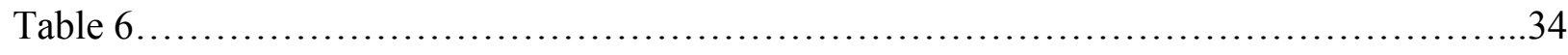

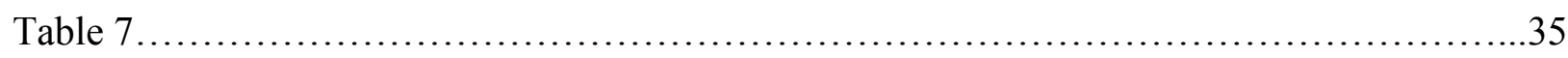

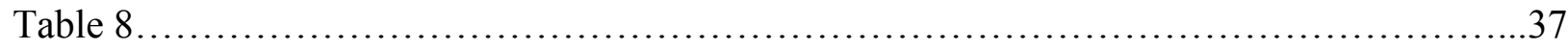

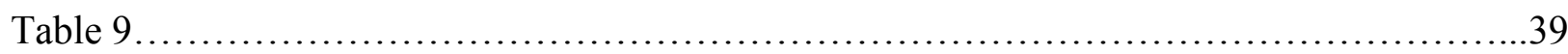




\section{LIST OF APPENDICES}

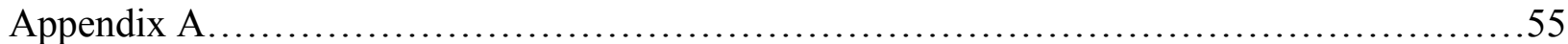

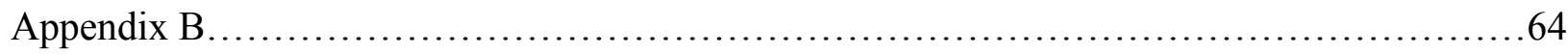

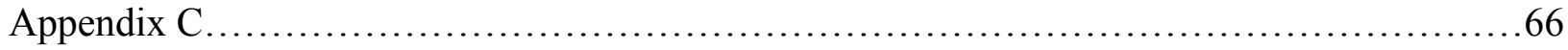

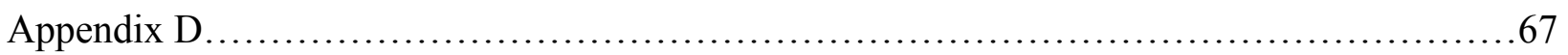

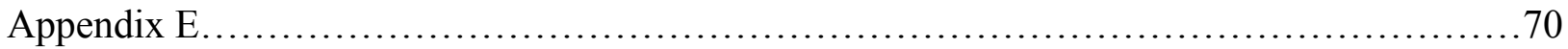




\section{INTRODUCTION}

In 2005, Robert Blake was acquitted of the charges he faced for allegedly shooting and murdering his wife, Bonnie Lee Bakley. The prosecution's case relied upon seemingly compelling circumstantial evidence that attempted to prove Blake's motive and opportunity to murder his wife. However, this evidence was deemed insufficient by the jury, and Blake was acquitted of his charges. The jury maintained that the prosecution "could not put the gun in his hand" when it failed to produce fingerprint evidence on the murder weapon or find gunshot residue on Blake's clothing (Cable News Network, 2005).

The Blake case was apparently lost because the prosecution could not produce the forensic evidence necessary for the jury to conclusively prove that Blake murdered his wife. This case demonstrates a recently held belief by lawyers and legal scholars that jurors have an increased expectation that forensic evidence be available in the most serious criminal trials (Cole \& Dioso-Villa, 2009; Tyler, 2006). As this type of evidence is difficult to collect and is often unavailable (Mancini, 2011), speculation as to cause of this increased expectation has commenced and is the focus of this research.

In some criminal trials, jurors are the triers of facts. Their role is to listen to the details of a case and render a unanimous decision as to the innocence or guilt of a defendant beyond a reasonable doubt. Jurors must consider all the available evidence and information carefully and render a verdict of guilty or not guilty. Jurors therefore play an important part in the criminal trials in which they are utilized. Thus, knowledge of their decision-making rationale is important and of potential benefit to those in the legal profession.

A jury's decision on a case affects the lives of those involved, from the defendant and the victim to the community at large. It is therefore not surprising that studies have explored 
numerous facets of criminal proceedings and the impact they have on jury decision-making. Because of the impact jurors have on case outcomes, researchers, lawyers, and legal scholars are interested in acquiring information that can help them win cases, change legislative policy, or further contribute to the knowledge-base regarding decision-making.

The present research explores the impact of scientific evidence, particularly DNA, and how jurors perceive this evidence when it is presented in a criminal trial. The emergence of DNA evidence in the courtroom has been increasingly relied upon in the past decade (Dale, Greenspan, \& Orokos, 2006). This is beneficial for the litigation process for several reasons. First, and most importantly, DNA evidence is a precise and accurate identifier when proper care is taken in the analysis process and good samples are retrieved from crime scenes (Saks \& Koehler, 2005). This allows judges and jurors to be more confident in their decisions, as testimony from an expert witness in DNA analysis is arguably less subjective than that of an eyewitness, for example. Secondly, DNA evidence has proven useful in exonerating those who have been wrongfully convicted of crimes (see The Innocence Project, 2011). The Innocence Project (2011) clearly demonstrates the need to further develop the DNA collection and analysis process as it saves victims and defendants from the negative consequences of an erroneous conviction.

Though DNA evidence in criminal trials is of great benefit, it is not always the case that such evidence is forthcoming. This can be for multiple reasons, but perhaps the most telling is that in cases where strong DNA evidence is obtained from a crime scene, plea bargains are often utilized and cases do not go to trial (Goodman-Delahunty \& Tait, 2006). Although jurors and lay people often perceive DNA evidence to be infallible (Lieberman, Carrell, Miethe, \& Kraus, 2008), they are often unaware of the fact that DNA matching is based on population base rates and that different samples yield different statistical levels of certainty that a particular sample 
belongs to a particular individual (Saks \& Koelher, 2005). Therefore, it is much more likely that when DNA evidence is presented as evidence in a trial, it is because of obvious weaknesses in the collection or analysis of the evidence, and that it is thus of weaker probative value than stronger samples (Goodman-Delahunty \& Tait, 2006). Debate has ensued on whether jurors are able to distinguish or recognize the weaknesses inherent in suboptimal samples of DNA evidence (Lieberman et al., 2008).

This notion has been seemingly problematic for judges and prosecutors who feel that recently, jurors are unwilling to convict defendants when DNA or forensic evidence are not presented as evidence (Cole \& Dioso-Villa, 2009). These legal professionals and social scientists have speculated as to why this is true (Tyler, 2006). As it stands, the championed hypothesis is that jurors get their information and facts regarding scientific evidence from popular crimedrama television shows, such as Crime Scene Investigation (CSI) (Tyler, 2006). Further, through gaining their knowledge from these sources, jurors believe the processes regarding the collection and analysis of DNA from crime scenes is simple, inexpensive, and error free (Cole \& DiosoVilla, 2007). This phenomenon has been aptly termed the CSI-effect, though studies attempting to demonstrate its existence have been largely unsuccessful thus far (Shelton, Kim, \& Barak, 2006; Podlas, 2006; Schweitzer \& Saks, 2007). Though the term "CSI-effect" designates the overarching belief of the availability and infallibility of DNA evidence just described, researchers know that measuring this overarching belief is improbable and unrealistic. A review of the research that has been conducted on the topic will be discussed in a subsequent section of this thesis paper.

As research in this field continues to grow, more is becoming known about how jurors perceive the presence of DNA evidence in the courtroom and how they subsequently use that 
evidence to render decisions.

\section{Perceptions of DNA Evidence}

The science of DNA matching is highly regarded as the "gold standard" against which other forms of scientific evidence are to be admitted and judged in court (Lieberman et al., 2008; Saks \& Koelher, 2005). Legal scholars and professionals have begun questioning why jurors increasingly expect the use of scientific evidence in trials (Cole \& Dioso-Villa 2007; Cole \& Dioso-Villa, 2009; Tyler, 2006). Though the understanding of this expectation is still unknown, scholars and legal professionals speculate that citizens believe they have a greater understanding of the nuances of DNA evidence than they once had (Brewer \& Ley, 2010).

Researchers are now beginning to explore the link between people's acceptance and perceptions of DNA evidence and popular media depictions of such evidence. Brewer and Ley (2010) note that from the early 1990's, American Gallup polls show that American citizens are becoming increasingly confident in their perceived understanding regarding the reliability of DNA. Brewer and Ley (2010) explore this upward trend in a study in which they hypothesize that the amount of media one consumes is directly related to self-perceived understanding of DNA and the level to which one believes the evidence is reliable. To test their hypotheses, the researchers surveyed 908 adult residents of the Milwaukee metropolitan area. From the surveys, the researchers found support that time watching television is positively related to the perception that DNA is reliable; heavy viewers found the evidence more reliable than lighter viewers. As well, viewers of crime-drama television reported higher self-perceived understanding of DNA evidence compared to non-viewers.

The research conducted by Brewer and Ley (2010) highlights a possible explanation for where people acquire their information regarding DNA and forensic evidence. What some 
empirical studies have shown, however, is that self-perceptions of key issues regarding DNA evidence are not applied accurately when evaluating DNA evidence in a trial scenario. Jurors are often unaware of qualities in the process of collecting and analyzing DNA that makes the evidence of weaker probative value. For instance, deficiencies in lab proficiency testing, analysis technique, quality control, and potential environmental contaminants pose inherent problems in the accuracy of results (Lieberman et al., 2008). If jurors perceive DNA evidence as being infallible, implications for trials where DNA evidence is used may become apparent. One such implication is that jurors might overly favour the litigating party that presents DNA evidence, while overlooking other relevant forms of evidence. An often-misunderstood quality of DNA and forensic evidence matching is that it is based on probabilities and is never a guarantee (Schweitzer \& Saks, 2007).

It is also a possibility that jurors bring with them inherent biases and favour litigating parties that possess DNA evidence. Or, more specifically, jurors may be more receptive to forensic evidence when it is presented by a particular litigating party (i.e., the Prosecution or the Defence). This notion was explored in a study conducted by Smith and Bull (2012), who attempted to validate a scale to measure jurors' preexisting biases of forensic evidence when brought forth individually by the Prosecution or Defence. In their development of the scale, the researchers found 10 items that measured the construct of pretrial bias for forensic evidence. These items were embedded into a 31-item measure and were used to create the Forensic Evidence Evaluation Bias Scale Pro-Prosecution (FEEBSpp) and the Forensic Evidence Evaluation Bias Scale Pro-Defence (FEEBSpd). To evaluate the scale, the researchers had mockjurors read a murder scenario and a trial summary that contained different types of evidence. Importantly, the DNA evidence utilized in the mock trial was "not of extremely high (or strong)" 
probative value and would thus allow the opportunity for juror bias to operate in the decisionmaking rationale of their participants (Smith \& Bull, 2012, p. 805). To ensure this, the researchers described a scenario in which a DNA sample extracted from a cigarette butt found outside the murder scene was matched to that of the defendant. Further, participants read testimony from an eyewitness, the arresting police officer, a pathologist, and the DNA laboratory analyst. The researchers found that the FEEBSpp significantly predicted the perceived strength of the DNA evidence, suggesting that jurors who hold pro-prosecution forensic evidence biases rate suboptimal DNA evidence as having a higher probative value than it deserves. This finding suggests that jurors may have more of a proclivity to find a defendant guilty when the prosecution brings forth suboptimal DNA evidence than they would to find the defendant not guilty when similar evidence is brought forth by the defense.

Whether it is the fact that jurors bring pre-existing biases to trial or that they are genuinely unable to distinguish between weak or ambiguous evidence remains an issue. The ambiguity or inherent errors in a piece of DNA evidence may be overshadowed by jurors' perceptions of the infallibility of DNA evidence (McQuiston-Surrett \& Saks, 2009). When DNA evidence is presented at trial, experts testify to the fact that DNA samples are based on the probability that a random individual selected from a population would have the same genetic markers as the person to whom the DNA sample is said to belong (McQuiston-Surrett \& Saks, 2009). This probability is known as the random match probability (RMP). Problematic to jury trials is the way in which experts describe this probability to jurors, which is commonly in the form of base rates. Base rates pose problems because population characteristics upon which a sample can be compared are often unknown (McQuiston-Surrett \& Saks, 2009). Scholars report that in cases where jurors are presented with complicated mathematical base rates, heuristic cues 
may be relied upon to render a decision as to the reliability of the testimony (Koehler, 2011; Lieberman et al, 2008). For instance, Koehler (2011) draws on exemplar cuing theory to explain how and when people might be persuaded by DNA RMP statistics. According to the theory, jurors will find the statistical presentation of DNA evidence compelling when they are not able to easily identify or compare other examples or situations when similar statistical comparisons could be made (Koehler, 2011). Exemplar cuing theory stems from Tversky and Kahneman's (1973) availability heuristic, which asserts that people have a proclivity to assign the prevalence of an event in accordance with the ease of which they can think of similar examples of that event occurring. In a similar vein, Lieberman and colleagues (2008) discuss the potential for jurors to evaluate DNA evidence based on the representations of high profile criminal cases for which DNA evidence played a prominent role, such as the OJ Simpson trial or the identification of Bill Clinton's DNA on Monica Lewinski’s dress.

Previous studies have determined that jurors diminish probabilistic values when they are provided with the presentation of DNA matching (Goodman, 1992; Koehler, 2011; Thompson, \& Schumann, 1987). The problem with unknown base rates and probability estimates has inhibited jurors' ability to accurately evaluate an expert's testimony, know the occurrence of an object's characteristics in a population, and determine how much weight should be placed on forensic evidence (Koehler, 2011; Schklar \& Diamond, 1999). As the problems just outlined are inherent in cases that rely on DNA evidence, researchers have conducted studies to determine the impact of DNA evidence on mock-juror judgments of the reliability of DNA evidence and the subsequent culpability of a defendant.

Three studies conducted by Lieberman and colleagues (2008) examined juror perceptions of the strengths and weaknesses of DNA evidence. The first two studies explored the extent to 
which jurors perceived the superiority of DNA evidence as being the "gold standard" against which other forms of forensic evidence are measured. The third study explored the extent to which jurors were able to recognize the inherent weaknesses of DNA evidence. Using a trial transcript and juror questionnaire, study 1 assessed potential jurors' perceptions of DNA and other forms of evidence commonly used in trials. The results of study 1 were consistent with general beliefs regarding the accuracy and persuasiveness of DNA evidence. Of the evidence presented to mock jurors in the questionnaire, $94.9 \%$ of jurors rated DNA evidence as the most accurate and $94.2 \%$ rated it as the most persuasive. Other forms of scientific evidence, such as fingerprinting, were also rated as more accurate and persuasive than nonscientific forms of evidence, including eyewitness testimony. Testing the final hypothesis of study 1, juror conviction rates were significantly higher when DNA was the primary incriminating evidence compared to any other form of evidence. This finding was also true in exonerating cases, leading to significantly more not-guilty verdicts when DNA was the primary exonerating evidence.

Study 2 replicated the results of study 1 but utilized an experimental design. The results of study 2 were similar to that of study 1 , with jurors being significantly more likely to convict with the presentation of DNA evidence than other forms of evidence.

In their final study, Lieberman and colleagues (2008) explored the degree to which jurors are able to appreciate the weaknesses inherent in DNA evidence by highlighting them in crossexaminations. In this $2 \times 2$ study, cross-examination (evidence-driven vs. expert-driven) and the reliability of the DNA laboratory (reliable vs. unreliable) were manipulated. The unreliable lab was created through demonstrating the lab's close affiliation to the local police force, its non-use of control samples, and finally by its lack of accreditation by the American Society of Crime Lab Directors (ASCLD), whereas the reliable lab was run independently of the local police force, was 
accredited by the ASCLD, and did use proper control samples. Cross-examinations were manipulated by either identifying weaknesses in the evidence, or by attempting to discredit the expert who was testifying to the results of the analysis. Results of this final study indicated that there were no main effects on juror verdicts regarding lab condition or cross-examination on verdict decisions. The results of study 3 were similar to that of studies 1 and 2 , indicating a significant effect on juror decision-making when DNA was presented as the primary evidence. Although the researchers failed to find main effects of lab condition or cross-examination on juror verdicts, some recognition of the limitations of DNA evidence were identified through a decrease in guilty verdicts from study 1 and 2. What is clear from Lieberman and colleagues' (2008) studies is that jurors weigh the value of DNA evidence heavily compared to other forms of evidence. Jurors rendered DNA evidence as the most accurate and most persuasive form of evidence over all other forms of evidence commonly presented in trials.

Similar results to Lieberman and colleagues' (2008) study were found by Golding, Stewart, Yozwiak, Djadali, and Sanchez (2000). These researchers explored the weight jurors attached to DNA evidence in comparison to the testimony of a 6 year-old victim of sexual abuse in a child sexual assault case. In part 1 of their study, the researchers explored the extent to which jurors valued DNA evidence in the presence and absence of testimony from the alleged victim, as compared to the testimony of the alleged victim alone. The researchers found that participants rendered more guilty verdicts when DNA corroborated the testimony of the child victim. DNA was also the factor that impacted jurors' decisions the most when their reasoning for convicting was assessed.

Further demonstrating DNA evidence's ability to outweigh other forms of opposing evidence in trials was a study conducted by Maeder, Ewanation, and Monnink (under review). In 
their study, participants read a second-degree murder trial transcript in which DNA evidence was manipulated to either increase or decrease its probative value in providing an accurate DNA match. These factors included proficiency testing and lab accreditation by an independent federal governing body, as well as cleanliness and organization of the lab (adapted from Lieberman et al., 2008). Further, contradictory eyewitness testimony was provided by a witness and was manipulated using markers known to increase or decrease jurors' confidence and perceptions of eyewitness testimony. Examples include the confidence an eyewitness states regarding the accuracy of his or her testimony (Brewer \& Burke, 2002) and the consistency of details provided by an eyewitness throughout all stages of criminal proceedings (Berman \& Cutler, 1996). In this fully crossed design, the researchers found that jurors preferred DNA evidence in every instance and provided favourable decisions to the litigating party that presented it. Importantly, DNA evidence of weak probative value was more influential in juror verdict than was strong, oppositional eyewitness testimony. This study demonstrates the ability of DNA evidence to outweigh traditionally strong forms of evidence when it is available. It also further demonstrates laypersons' inability to identify inherent weaknesses in a piece of DNA evidence (Maeder, Ewanation, \& Monnink, under review).

These studies underline important findings regarding the use of DNA evidence by mock jurors. They highlight the conclusion that jurors place a great deal of trust in DNA evidence, believing it to be a largely infallible and a highly reliable form of evidence. These studies also demonstrate the fact that jurors are not always able to identify the inherent weaknesses in DNA evidence when they exist. Because of what we know about the way jurors react to DNA and forensic evidence, scholars have begun examining instances where forensic evidence is not available (Podlas, 2006). They have done so in response to prosecution lawyers' belief in the 
decrease of conviction rates when they fail to provide the jury with forensic evidence. These legal actors claim that jurors have an undue expectation in the availability of forensic evidence and that this expectation has raised their burden of proof to unreasonable levels. Thus, the CSIeffect has become a contentious area of research. If this effect does influence jurors, reliability of several fundamental processes of the litigation procedure will be challenged.

\section{The CSI-Effect}

Investigation pertaining to the existence of the CSI-effect is still in its infancy and commenced mostly in response to the popular media's reporting of the effect after the acquittals of defendants in highly publicized criminal cases (Tyler, 2006). Though CSI debuted in the year 2000, empirical research did not commence until the mid-point of the decade. Often, researchers define the CSI-effect as the impact of crime-drama television on jurors' expectations and use of forensic evidence (Roane, 2005). This construct, however, is too broad to measure and has proven necessary to break down further. More specifically, researchers have explored the ways in which jurors are biased by the show's portrayal of forensic evidence. Subsequently, five prominent CSI-effects have been identified and attempts to prove these effects' existence have been undertaken. They are as follows: 1) CSI increases jurors' expectations that forensic evidence be presented in trials, thus increasing the prosecution's burden of proof; 2) When forensic evidence is presented, jurors over-value the evidence's probative value and deem it infallible; 3) CSI has made jurors more knowledgeable and able to evaluate forensic evidence more accurately when it is presented in trials; 4) CSI has increased the popularity in forensic science programs among applicants to university programs; and 5) CSI has increased criminals' ability to evade detection of crimes (Cole \& Dioso-Villa, 2007; Cole \& Dioso-Villa, 2009; Podlas, 2006). So far, however, the research supporting any one of these CSI-effects has been 
less than convincing (Podlas, 2006; Schweitzer \& Saks, 2007; Shelton et al., 2006).

Of the outlined effects, researchers have focused their attentions to the notion that the CSIeffect has increased the prosecution's burden of proof in criminal trials. In their attempt to test this idea, results have alluded to or provided some evidence for this and the other effects, but early research has largely been mixed, and strong evidence of the existence of any single effect does not exist (Podlas, 2006; Schweitzer \& Saks, 2007; Shelton et al., 2006).

Early research on the CSI-effect attempted to explore different constructs of the effect by quantifying participants as high-frequency and low-frequency viewers, or slight variations thereof (e.g., viewers vs. non-viewers) of crime-drama television (Podlas, 2006; Schweitzer \& Saks, 2007; Shelton et al., 2006). The popular belief held by these researchers was that highfrequency viewers are more likely to endorse biased decision-making caused by their interaction with crime-drama programming than are low-frequency viewers. For instance, Podlas (2006), in what is now a highly cited paper, tested the prosecution burden of proof CSI-effect by first distinguishing between high-frequency and low-frequency viewers of CSI and related crimedrama programming by having participants respond to a television viewing habits questionnaire. She then had participants render a verdict based on a one-page case synopsis in which the only legally correct verdict was "not guilty" and of which the inclusion or exclusion of forensic evidence was irrelevant to the case. Participants were then required to select one of seven evidentiary reasons as to why they voted not guilty. Three of those seven possible reasons related to a lack of forensic evidence and were thus labeled as "CSI-marked reasons." It was hypothesized that heavy viewers of CSI and law-related television would select the "CSImarked reasons" for their verdicts more often than non-heavy viewers (459). This was not the case, however, and statistical analysis comparing frequent and infrequent viewers' responses 
yielded no significant differences in their reasons for rendering not-guilty verdicts. Thus, Podlas' (2006) study did not support the hypothesis of a CSI-effect that raises the prosecution's burden to produce forensic evidence at trial.

In another study, Shelton and colleagues (2006) found that a sample of respondents classified as "frequent CSI-watchers" had increased expectations of not only scientific evidence, but also all types of evidence across a variety of crime scenarios. Further, the researchers found that CSI-watchers had higher expectations of scientific evidence in cases where scientific evidence was more relevant than did non CSI-watchers. At first glance, these results appear to provide evidence of increased expectations by jurors. Importantly, however, when comparing CSI-watchers to non CSI-watchers, there was no significant difference between groups in the demand for scientific evidence as a requisite to find the defendant guilty.

In a similar study, Schweitzer and Saks (2007) presented participants with an 11-page criminal trial scenario in which a hair left by the perpetrator at the scene of the crime was matched to that of the defendant as the primary evidence. Participants were classified as viewers (watched CSI and its spinoffs at least once per month) and non-viewers (had never seen the show). Schweitzer and Saks (2007) found that, contrary to popular belief, viewers of crimedrama programs were more critical of the evidence than were non-viewers. The researchers then posited that their finding supports the notion that viewers of CSI are more critical of weaker forms of evidence and demand more sophisticated techniques, thus increasing the prosecution's burden of proof. Although CSI viewers were slightly more critical of the forensic evidence than the non-viewers, no significant differences were found between the two groups' decisions to convict or acquit.

These three early studies highlight the fact that the influence of crime-drama programming 
might influence jurors differently depending on the context and case-specific circumstances. Though it appears CSI-watchers demonstrate a raised expectation for the presence of forensic evidence, this raised expectation was unrelated to verdict decisions. This is in important facet for the applicability of this research, as a raised expectation of specific evidence is inconsequential if it does not bias the decision-making process of jurors. Further, the results of these studies provide some support that there is not a single CSI-effect that operates on viewers of crimedrama programming in a predictable direction. The above studies paved the way and provided some useful insights into the barriers and methodological limitations that future research has to overcome in order to better understand the CSI-effect. Of these limitations, a few are worth discussing as they relate directly to where future research should be headed. First, these studies can not demonstrate a causal relationship between crime-drama television consumption and verdict decision because program consumption is not a controlled variable.. A problem with designing experimental studies is controlling for the amount of crime-drama programming a participant views prior to partaking in the study. Obtaining the proper control of independent variables when attempting to study the relationship between juror verdicts and television viewing may not be possible, as most people have unlimited access to and have seen television programs previously Another limitation of these studies is that they have all failed to report effect sizes (Podlas, 2006; Schweitzer \& Saks, 2007; Shelton et al., 2006). This is an important consideration, as an independent variable can still affect the dependent variable without reaching the cut-off for statistical significance. Reporting effect sizes can guide future research and provide insight into the strength of relationships among variables.

Secondly, these studies have not looked beyond the consumption of crime-drama television programming to offer any alternative explanations for a CSI-effect. Though it is 
logical to surmise that these programs might have the largest impact on shaping perceptions and knowledge of DNA evidence, it could be the fact that other types of programs influence juror knowledge as well. For instance, heavy viewers of crime-drama programs are also likely to be heavy viewers of television in general. It cannot be said with certainty to what degree other types of programs might influence juror knowledge and perceptions of DNA evidence, such as the consumption of news media, for example.

Finally, it is perhaps that these studies lack solid theoretical explanations for how CSI and crime-drama programming influence juror expectations of forensic evidence (Brewer \& Ley, 2010). Researchers have turned predominantly to research in communication to provide a theoretical foundation to explain how CSI and similar programming might influence the way jurors perceive DNA and forensic evidence.

\section{Cultivation}

Although empirical research studies pertaining to the CSI-effect are few and far between, the subject as a topic of research is young and knowledge is being gathered. As it stands, the empirical studies that have sought to prove or disprove the CSI-effect are criticized for lacking a theoretical foundation upon which to formulate hypotheses and test constructs (Ley et al., 2012). Much of the other exploratory research on the CSI-effect, however, has drawn on various theories to explain how television viewers are influenced by the programs they watch. Of the leading theories, researchers have drawn predominantly on cultivation theory, with some interaction from social cognitive theory and audience reception studies (Brewer \& Ley, 2010; Hayes \& Levett, 2009; Ley et al., 2012; Podlas, 2006).

Cultivation theory became popular in the mid 1970's, when more and more households came in possession of televisions and programming became more widely consumed. The theory 
was championed by George Gerbner during a time of social distress in which television was thought to be causing violent behavior (Gerbner \& Gross, 1976; Morgan, Shanahan, \& Signorielli, 2012). Thus, out of a time when media depictions of violence were thought to directly impact viewers' behavior, Gerbner defined "cultivation" as "the process within which interaction through messages shapes and sustains the terms on which the messages are premised" (Gerbner, 1963; Morgan et al, 2012, p.2). For Gerbner, television was becoming the most prominent message provider in a society in which people were no longer receiving messages from traditional sources, namely, those that were passed along directly from older generations (Gerbner \& Gross, 1976). Though television has evolved a great deal from the 1970's, cultivation theory has evolved as well to provide explanations as to how people might be influenced differently regarding different genres and types of programming.

In their book, Living with Television, Morgan et al. (2012) outline popular methods of cultivation analysis that can be used to measure the influence of television genres on its viewers. They outline that the most common method to do this is to "first identify stable patterns in television content, emphasizing the consistent images, portrayals, and values that cut across programs" (p.5). The authors note that this is typically accomplished with content analyses. Once the patterns are established, researchers can distinguish between viewers by the quantity of television they consume and compare opinions, beliefs, or attitudes accordingly using survey methods. This method has been utilized across a variety of television genres, from support of Agriculture Biotechnology (Besley \& Shanahan, 2005) to science and technology (Gerbner, Gross, Morgan, \& Signorielli, 1981; Nisbet, Scheufele, Shanahan, Moy, Brossard \& Lewenstein, 2002). Notably, these survey methods have also been used to explore the influence of crimedrama programming on juror perceptions of forensic evidence. 
For instance, Brewer and Ley (2010) conducted a survey with 908 jury-eligible adults to explore the effects of media on self-perceived understanding of DNA evidence, the reliability of DNA evidence, and the weight DNA evidence should receive in a trial. Survey results indicate that the amount of time participants spent watching crime-television programming was correlated to higher ratings of self-perceived understanding of DNA and belief in its reliability. Importantly, however, viewers of crime-television programming did not differ from non-viewers in the way they voted in jury decision-making scenarios. This finding thus provides partial support for the view that crime-drama programming impacts jurors' self-perceived knowledge of DNA evidence, but importantly does not speak for differences in their willingness to convict or acquit when forensic evidence is or is not forthcoming. Survey studies such as this one are few in number and largely exploratory. Further, they are based primarily on speculation that CSI and like programming actually portray forensic techniques in an unrealistic matter. It is thus beneficial that researchers have begun to examine the shows' content so that an appropriate theoretical foundation can guide future studies.

In what is the most thorough content analysis of the show, Ley et al. (2012) dissected the popular show Crime Scene Investigation's (CSI) portrayal and use of DNA. The goal of their content analysis was to provide the foundation for the genre-specific cultivation effect that has been thought to exist from observational and survey accounts. The researchers randomly selected 51 episodes from the first 6 seasons of the show in an attempt to provide an explanation for how it is possible that the show's portrayal of DNA collection and analysis is biasing jurors. The results of the content analysis revealed some important findings: First, DNA was searched for in $66 \%$ of investigated cases and in $86 \%$ of episodes; the search process was depicted as a routine procedure. Second, the show's actors were successful in their search for DNA in $61 \%$ of 
investigated cases and in $84 \%$ of episodes. Finally, DNA matches helped the show's investigators solve $26 \%$ of the show's entire investigated cases. The researchers conclude that the show's depiction of DNA testing is unrealistically simple, reliable, and crucial to solving cases (Ley et al., 2012). Their finding supports a statement made by Houck (2006), a forensic consultant for the television show, who claims that $40 \%$ of the science depicted in the program does not actually exist.

Through this content analysis, the researchers provide support that CSI and like programming are in fact portraying DNA and forensic evidence in a manner that consistently exaggerates real-world techniques. It could be argued, however, that this content analysis has just demonstrated what was already known - that CSI and similar crime-drama programs are known fictions and do not have to reflect reality. A possible explanation is that through many years of television consumption, viewers have become aware that a large portion of television content exists for the purposes of entertainment and does not have to reflect real-world occurrences. This may lead viewers to be more critical of the media they consume when evaluating the realism of particular shows or genres. It is thus the contention that studies examining the CSI-effect can no longer look merely at consumption quantity, but must also look at the degree to which viewers believe the program they are watching is reflective of real-life. More specifically, it is believed that CSI-effects will be consistently active in individuals who perceive what they are viewing as reflective of reality.

\section{Perceived Realism}

It has been generally accepted among researchers that television has the ability to cultivate messages in its viewers (Gerbner \& Gross, 1976; Gerbner, Gross, Morgan, \& Signorielli, 1994). It has been difficult to demonstrate, however, how these cultivated messages 
manifest themselves in the decisions or judgments viewers make regarding genre-relevant topics. In response to this, researchers have shifted their focus to not only how much television programming one consumes, but also how viewers perceive these programs to reflect possible practices in their everyday lives. In terms of media effects, Busselle and Bilandzic (2012) define perceived realism as "the extent to which viewers judge that the people and events they encounter in media are portrayed as would be expected, given the socially constructed understandings of the actual world that a given viewer brings to the media experience" (169). Further, some evidence suggests that those who perceive what they are viewing to be reflective of reality will be more influenced by it than those who do not (Potter, 1986, Quick, 2009). For instance, Taylor (2005) compared to the degree to which participants in a study endorsed sexually permissive behavior based on the degree to which they perceived television content to be realistic. Participants were either placed in a no-viewing control group, a viewing control group with non-sexual content, a non-verbal viewing group where sexual content was discussed but not depicted, or a visual sexual depictions group. The researcher found a significant interaction between perceived reality and the viewing of sexually permissive content; viewers who viewed sexual content and rated it as realistic endorsed more sexually permissive attitudes than viewers who scored low on perceived reality. This study demonstrates the influence that television content can have on various attitudes when viewers believe that content to be reflective of real-life.

Research exploring the relationship between television consumption and perceived reality has provided support for a positive relationship between these two variables on aspects of viewers' decision-making or cognitive availability. For instance, Busselle (2001) explored the relationship between exemplar accessibility (the degree to which participants could think of 
examples regarding selected social constructs), perceived realism, and television consumption. To test this relationship, the researcher had participants make social judgments upon three social constructs: 1) a husband or wife having an affair; 2) a black medical doctor and; 3) someone shot with a gun. First, participants responded to a set of questionnaires that measured television consumption, perceived realism of television, and demographics. In subsequent weeks, the participants returned to participate in a seemingly different study. Upon returning, participants gave social judgments (the degree to which participants thought these social constructs occurred in real-life) in which they either made a judgment first regarding the occurrences of the social constructs followed by a task requiring them to think of relevant examples of that social construct (exemplar accessibility task); or were given the exemplar accessibility task then told to make judgments. Busselle (2001) hypothesized that television consumption and perceived realism would both be positively related to increased social judgments when judgments were made prior to the completion of the exemplar accessibility task. The researcher also predicted that television consumption and perceived realism would be positively related to the ease with which participants were able to draw on relevant examples when the exemplar accessibility task was completed prior to making social judgments.

Based upon Shrum, Wyer, and O'Guinn's (1998) heuristic model of cultivation effects, Busselle's (2001) hypotheses were formulated on the grounds that heavy consumers of television have greater exposure to certain social constructs because television acts as a natural prime when evaluating the occurrences of these social constructs. His hypotheses were further defined with research supporting the notion that information is more accessible for people when they perceive that information to be real rather than fictional (Prentice \& Gerrig, 1999).

Busselle (2001) found partial support for his hypotheses. Television consumption prior to 
the exemplar accessibility task predicted two of the three social judgments, excluding doctors who are black. Further, when asked to make judgments first in the "someone shot with a gun" construct, perceived realism of television crime/emergencies was positively related to the degree to which participants thought this construct occurred in real life. That is, participants who perceived crime/emergency programming as reflective of reality believed that someone being shot with a gun occurred more often than those who did not perceive that type of programming as reflective of reality. Importantly, this relationship occurred before the exemplar accessibility task was administered, suggesting this programming acted as a prime for participants who scored high on perceived reality measures. Overall, Busselle's (2001) study suggests that television exposure and perceived reality of programming have the ability to influence people's perceptions regarding the occurrences of certain social phenomena. Having participants think of examples before making judgments regarding these constructs was shown to weaken the influence of television exposure and perceived reality on judgments (Busselle, 2001).

Research has also begun to explore how program specific cultivation and perceived reality affects the judgments made by participants regarding the topics those shows depict. For example, exploring how cultivation and perceived reality influences patients' perceptions and satisfaction with their doctors, Quick (2009) examined participants' viewing habits of the popular show, Grey's Anatomy. Quick (2009) found that heavy viewers of the show thought it was a credible depiction of the medical profession. Further, the researcher found evidence that participants who perceived the show's depiction of doctors as reflective of reality found that they also believed real-world doctors are courageous (as this is how the doctors on the show are depicted). Although this research was not conducted using crime-drama programming, it suggests that similar program or genre-specific effects could be found. The results of Quick's (2009) study 
further suggests that similar conclusions may be drawn about those who perceive crime-drama television shows such as CSI to be reflective of reality as both shows operate on the same premises and both exaggerate depictions of the subject matter they present.

Exploring the crime-drama sub-genre, Maeder and Corbett (2015) conducted what is currently the only study that specifically explores the relationship between crime-drama programing, television consumption, perceived realism, and jury decision-making. In their study, participants read a case summary for a second-degree murder and were then given a trial transcript in which the prosecution presented incriminating DNA evidence and the defense presented exonerating eyewitness testimony. The participants then answered a number of questionnaires that explored the following: 1) the impact each evidence type had on mock-juror verdicts, 2) verdict confidence, 3) attitudes towards eyewitness testimony and DNA evidence, and 4) the frequency with which participants watched crime-drama television and the degree to which they believed those programs to be reflective of reality.

Maeder and Corbett's (2015) study revealed some interesting findings. First, no significant association was found regarding television consumption quantity, perceived realism, and the interaction between the two variables on juror verdicts, indicating that these variables were not directly related to juror verdicts. Interestingly, however, correlational analyses revealed a significant relationship between participants' perceived realism of crime-drama television and attitudes toward both DNA evidence and eyewitness testimony, which was subsequently explored further using path analysis. Using perceived realism and television consumption as predictor variables, the analysis revealed significant direct and indirect effects on juror verdicts, which operated through attitudes and perceptions of the DNA and eyewitness testimony. Importantly, the model explained $60 \%$ of the variance in mock-jurors' certainty that the 
defendant was guilty. Further, perceived reality of crime-drama programming significantly predicted the influence of DNA evidence on mock-jurors' ratings of guilt. Participants who perceived crime-drama programming as reflective of reality were more influenced by the DNA evidence presented by the Crown.

This study by Maeder and Corbett (2015) reveals new pathways in which perceived reality of crime-drama television may impact juror-verdicts in certain criminal cases. Further, it supports earlier findings that television consumption alone does not directly cause the manifestation of CSI-effects among potential jurors (Podlas, 2006; Schweitzer \& Saks, 2007; Shelton et al., 2006). The path analysis, however, uncovers some of the possible factors that may be influential in impacting juror verdicts, including the degree to which mock-jurors think crimedrama television reflects everyday DNA collection and analysis practices. This path analysis offered an interesting examination regarding the relationship between perceived realism and television consumption on mock-juror verdicts and its appropriateness for use in decisionmaking studies that extrapolate its results to real-world cases, for which no two are the exact same. Importantly however, this study could not explain how perceived reality would affect mock jurors' decisions when the prosecution did not present DNA evidence. The exploration of this condition will be at the forefront of the study presented here, and will help further answer questions regarding the supposed increased expectation jurors have that the prosecution present DNA evidence in criminal trials.

\section{The Current Study}

Building on previous research, it is the contention here that CSI-effects must no longer be evaluated through dichotomous comparisons of viewers vs. non-viewers (Podlas, 2006; Shelton et al., 2006; Schweitzer \& Saks, 2007). Given the literature regarding the relationship between 
perceived reality of television programming on judgments and decision-making, it is only appropriate that this variable be explored further in a criminal trial setting. Building off Maeder and Corbett's (2015) study, the research presented here further expands what is known about the relationship between perceived realism and juror decision making in a criminal trial that presents either DNA evidence, eyewitness testimony, or fingerprint analysis.

Maeder and Corbett's (2015) study examined the relationship between the prosecution's use of DNA evidence, the defence's use of eyewitness testimony, the amount of crime-drama television participants watched, and the degree to which they believed those programs reflected real-life practices. Though a good starting point, it is the contention here that manipulations of the use and exclusion of DNA evidence by the prosecution must be explored further. Specifically, further examination must be taken regarding situations in which the prosecution fails to present DNA evidence in criminal cases, as it is the principal complaint among lawyers and judges that jurors will not convict when this is the case (Cole \& Dioso-Villa, 2009). With that understanding, this study explores juror decision-making as a function of the presence or absence of DNA evidence from the side of the prosecution in a criminal trial. This study also includes the exploration of another type of forensic evidence (i.e., fingerprint analysis), as well as eyewitness testimony in an attempt to understand how participants distinguish between different types of evidence, and manipulates evidence strength to determine whether jurors would be sensitive to the difference in strong and weak evidence. Finally, it explores the association between perceived realism of crime television programming and verdict outcomes.

\section{Hypotheses}

H1a: Juror conviction rates will be significantly greater when the prosecution presents DNA evidence than when they present fingerprint evidence or eyewitness testimony (Golding et 
al., 2000; Lieberman et al., 2008; Maeder, Ewanation \& Monnink, under review).

$\mathrm{H} 1 \mathrm{~b}$ : Conviction rates will differ between strong and weak forms of fingerprint evidence and eyewitness testimony, but not DNA evidence, further highlighting the fact that jurors have difficulty perceiving weaknesses in DNA evidence (Lieberman et al., 2008). Specifically, it is predicted that juror verdicts will differ as a result of an interaction between evidence strength and evidence type, such that evidence strength will affect verdicts in the fingerprint and eyewitness conditions, but not in the DNA condition. Though fingerprint analysis is a form of forensic evidence, testimony regarding a match or non-match is not based upon statistics or population base-rates such as DNA evidence. Rather it is based upon the subjective interpretation made by the analyzer, whose degree of accuracy may differ as a function of experience. Therefore, it is predicted that mock-jurors will be more able to distinguish between weak and strong forms of fingerprint analysis than they are with DNA evidence.

H2a: Because television's influence on attitudes and behavior has been shown to increase with the degree an individual believes that television reflects reality (Potter, 1986; Quick, 2009), it is predicted that participants who perceive television to be reflective of real-life will be more critical of fingerprint evidence and eyewitness testimony than DNA evidence, resulting in lower conviction rates when DNA evidence is not present. This hypothesis is further supported as DNA evidence on television is consistently portrayed as abundantly available and infallible (Ley et al., 2012).

H2b: Additionally, participants who score high on the perceived realism scale (Busselle, 2001) will be less influenced by - and report more negative attitudes towards - eyewitness and fingerprint evidence than participants who score low on perceived realism. This is predicted because of the purported relationship between perceived reality and the portrayal of DNA 
evidence on television. Because television exaggerates the abilities and properties of DNA evidence, it is predicted that participants who believe television reflects real-life practices will be critical of any evidence that is not DNA, as misguided messages regarding DNA evidence have been cultivated in their decision-making process.

\section{METHOD}

\section{Participants}

Participants for this study were gathered online using a sample drawn from Mechanical Turk (MTurk). All participants $(\mathrm{N}=386)$ were jury-eligible American citizens. This means participants were: 1) citizens of the United States, 2) at least 18 years old, 3) not currently subject to felony charges of which a prison sentence of one year may be served, and 4) not convicted of a felony charge, unless a full pardon has been granted. Of the total participants, 11 failed an attention check and 93 discontinued the survey after starting. Thus, 282 responses were analyzed. The participants for this study were 181 (64\%) women, $100(35 \%)$ men, and 1 (.5\%) transgendered, ranging in age from 18 to 71 years old $(\mathrm{M}=36.4, \mathrm{SD}=11.2)$. Participants ranged in ethnic diversity with 209 (74.1\%) Caucasian, 17 (6\%) Hispanic/Latino, 24 (8.5\%) AfricanAmerican, 15 (5.3\%) East-Indian, 12 (4.3\%) Asian, 3 (1.1) American-Indian, and 2 (.7\%) Middle Eastern. Participants were compensated with $\$ 2$ dollars for their completion of the study.

\section{Design}

A 3 (Evidence type: DNA vs. Fingerprint vs. Eyewitness Testimony) X 2 (Evidence strength: Strong vs. Weak) factorial design was utilized for this study. The case synopsis and trial summary were the same for all conditions except for manipulations made to the evidence presented by the prosecution.

\section{Materials}


Case summary. In each condition, a one-page summary was provided to participants describing a murder that took place in a local park (see Appendix A). The summary describing the murder was the same for all conditions except for manipulations in the evidence that is brought forth by the prosecution.

Trial transcripts. Six trial transcripts were used in this study to represent the outlined conditions (see Appendix A). All transcripts were essentially the same in content and length (approximately seven pages), but differed depending upon the evidence that was presented by the prosecution. Participants read the testimony of either an expert witness presenting DNA evidence, an expert witness presenting fingerprint analysis, or an eyewitness who saw the crime take place. Additionally, within each of those three possible evidence type conditions, participants read testimony in which the evidence was manipulated to contain strong or weak markers meant to increase or decrease the evidence's probative value. In the strong DNA condition, a clean blood sample was found at the crime scene and was analyzed by an independent forensics laboratory that is accredited by the American Society of Crime Lab Directors (ASCLD). In the weak DNA condition, the forensics laboratory was not accredited and possible contamination issues were made salient. For participants in the strong fingerprint analysis condition, the expert witness testified that the fingerprints taken from the murder weapon were of high quality and easily comparable to the fingerprints taken from the defendant in a controlled setting. Further, the expert witness was a highly competent analyzer as was shown through his managerial role and his lab's national accreditation. In the weak fingerprint condition, a relatively inexperienced technician testified with a lesser degree of confidence that he believed there was a fingerprint match between the defendant and the prints taken from the murder weapon. Finally, in the strong eyewitness condition, a park custodian testified with a 
high degree of confidence that the defendant was the murderer. The custodian is able to state this as the park had good lighting, he witnessed the defendant in the park earlier in the evening, and the defendant ran right past him as he was fleeing the scene. In contrast, the weak eyewitness condition manipulated the degree of confidence the eyewitness had that he could accurately identify the defendant as the murderer. The confidence an eyewitness displays in his or her testimony, though not a strong indicator of recall accuracy, has been shown to be the strongest predictor in jurors' assessment of eyewitness credibility (Brewer \& Burke, 2002; Leippe \& Romanczyk, 1989; Lindsay, Lim, Morando \& Cully, 1986) and was thus a crucial distinction between the strong and weak eyewitness testimony conditions. This weak eyewitness condition further manipulated the length of time the custodian was able to see the defendant before the commission of the crime, the lighting under which the murder took place, and the fact that the murderer ran off in the opposite direction when fleeing the scene. In every condition, the Defence presented the testimony of a witness who provided an alibi for the accused. This testimony was the same across every experimental condition. The testimony regarding the presentation of DNA evidence was adapted from Lieberman and colleagues' (2008) study. The other conditions contained the same structure and language but differed regarding the evidence they discussed and were created by the researcher for this study.

Measures. After reading the trial summary and trial transcript, participants answered a series of questionnaires. First, participants responded to questions on a juror questionnaire (see Appendix C). Participants rendered a verdict of guilty or not guilty regarding the second-degree murder charge.

Following the juror questionnaire, participants responded to a 19-item Attitudes Towards Evidence Scale (see Appendix D). This scale assessed the attitudes held by participants regarding 
the efficacy of DNA evidence (questions adapted from Lieberman et al., 2008), fingerprint analysis, and eyewitness testimony (Narby \& Cutler, 1994) to be used to solve a crime.

Participants then responded to a 14-item Perceived Realism scale (Busselle, 2001) (see Appendix E). This scale asked participants to evaluate how accurately they believe television portrays certain aspects of every-day life. Participants respond to the questions on a scale ranging from -3 (not at all true) to 3 (very true). This 14 -item scale assessed three factors of perceived realism as it relates to television viewing and were subsequently assessed for reliability in Busselle's (2001) study. These factors are: perceived realism of crime and emergencies $(\alpha=.68)$, television news $(\alpha=.67)$, and relationships on television $(\alpha=.78)$.

Juror instructions. Upon reading the case summary and trial transcript, participants were provided with juror instructions (see Appendix B) regarding burden of proof, reasonable doubt standard, and the murder charge. The juror instructions provided were taken from the Judicial Council of California Criminal Jury Instructions.

\section{Procedure}

Participants were MTurk workers who completed the study online. Upon completing the informed consent, participants read 1 of 6 possible trial transcripts. After reading the stimulus materials, participants completed the juror questionnaire, the Attitudes Toward Evidence Scale, and finally the Perceived Realism scale. Participants were then shown a debriefing form, which explained the purpose of the study and whom they could contact with questions. They were then thanked for their time and compensated.

\section{RESULTS}

In total, analyses were conducted on a total of $\mathrm{N}=282$ participants. Table 1 and 2 describe the breakdown of verdicts by evidence type and descriptive statistics for all dependent variables. 
Table 3 describes the gender distribution and dichotomous verdicts across the evidence conditions.

Table 1.

Summary of verdict decisions across each evidence type condition

\begin{tabular}{llcc}
\multicolumn{1}{c}{ Evidence Type } & $\begin{array}{c}\text { Evidence } \\
\text { Strength }\end{array}$ & Verdict & \\
\hline \multirow{2}{*}{ DNA } & & Guilty & Not Guilty \\
\multirow{2}{*}{ Eyewitness } & Strong & 31 & 15 \\
& Weak & 26 & 26 \\
\multirow{2}{*}{ Fingerprint } & Strong & 22 & 28 \\
& Weak & 3 & 41 \\
& Strong & 22 & 22 \\
\hline
\end{tabular}

Table 2 .

Descriptive statistics for all dependent variables

Scale

\begin{tabular}{lcc}
\hline & Mean & SD \\
\hline Perceived Realism & -8.19 & 13.85 \\
DNA Attitudes & 36.54 & 8.9 \\
Eyewitness Attitudes & 47.82 & 14.6 \\
Fingerprint Attitudes & 29.04 & 10.1 \\
\hline
\end{tabular}


Table 3.

Distribution of participant gender and dichotomous verdict across evidence condition.

$\begin{array}{llll}\text { Condition } & \text { Gender } & \text { Verdict }\end{array}$

\begin{tabular}{|c|c|c|c|c|c|c|}
\hline & Men & Women & Trans & $\begin{array}{c}\text { Condition } \\
\text { Totals }\end{array}$ & Guilty & Not Guilty \\
\hline DNA & 33 & 65 & & $98(35 \%)$ & 57 & 41 \\
\hline Eyewitness & 37 & 57 & & $94(33 \%)$ & 25 & 69 \\
\hline Fingerprint & 30 & 59 & 1 & $90(32 \%)$ & 44 & 46 \\
\hline \multirow[t]{2}{*}{$\mathrm{N}=282$} & 100 & 181 & 1 & & 126 & 156 \\
\hline & $(35.5 \%)$ & $(64 \%)$ & $(.5 \%)$ & & $(44.8 \%)$ & $(55.2 \%)$ \\
\hline
\end{tabular}

Hypothesis 1a predicted that participants would render more guilty verdicts in the DNA evidence condition than they would in both the eyewitness testimony and fingerprint analysis condition. This hypothesis was supported. As can be seen in Table 4, more guilty verdicts were rendered in the DNA evidence condition $(n=57)$ than the eyewitness testimony $(n=25)$ and fingerprint analysis $(n=44)$ conditions. Chi-Square analysis did reveal a significant association between evidence type and verdict outcome $\chi^{2}(2, \mathrm{~N}=279)=20.29, \mathrm{p}<.001, v=.27$. A post-hoc logistic regression analysis revealed a significant difference between DNA evidence and eyewitness testimony, $\mathrm{b}=-1.35, \mathrm{p}<.001, \mathrm{OR}=.261$. Conversely, the DNA evidence and fingerprint analysis conditions did not differ significantly, $b=-.37, p=.203, \mathrm{OR}=.688$. Table 3 summarizes the results below. 
Table 4

Summary of logistic regression analysis predicting the impact of evidence type on verdict $(N=$ 282).

\begin{tabular}{lccc}
\hline Predictor & B & SE & OR \\
\hline Eyewitness & $-1.35^{*}$ & 0.311 & 0.261 \\
Testimony & & & \\
Fingerprint Analysis & -0.37 & 0.294 & 0.688 \\
\hline
\end{tabular}

Note: DNA evidence is used as the reference group.

$* p<.001$

Hypothesis $1 \mathrm{~b}$ predicted an interaction between evidence strength and evidence type on verdict decisions, such that conviction rates would differ between strong and weak forms of eyewitness testimony and fingerprint analysis, but would remain statistically equivalent for strong and weak forms of DNA evidence. To test this hypothesis, a logistic regression analysis was conducted with evidence type and evidence strength as predictor variables and dichotomous verdict as the outcome variable. Results of the analyses are summarized in Table 5.

Results of the analysis revealed a main effect of eyewitness testimony and a significant interaction between eyewitness testimony and evidence strength on dichotomous verdict. More specifically, when all other variables are held constant, being in the eyewitness testimony condition decreased the odds of voting guilty approximately $14(\mathrm{~b}=-2.62, \mathrm{OR}=.073)$ times compared to those in the DNA condition. Similarly, the significant interaction states that when variables are held constant, participants were $5.2(b=1.65, \mathrm{OR}=5.2)$ times more likely to vote guilty in the strong eyewitness testimony condition than those in the weak eyewitness condition. 
Interestingly, no significant difference was found between fingerprint analysis and DNA evidence in affecting juror ratings of guilt. Further, no significant differences were found between the strong and weak fingerprint analysis conditions.

Table 5

Summary of logistic regression predicting the impact of evidence type and evidence strength on dichotomous verdict $(N=282)$.
B
SE
OR

\section{Predictor}

\begin{tabular}{lccc}
\hline Eyewitness Testimony & $-2.62^{*}$ & .66 & .073 \\
Fingerprint Analysis & -.087 & .41 & .92 \\
Evidence Strength & -.726 & .42 & 2.10 \\
Eyewitness Testimony X & $1.65^{*}$ & .78 & 5.20 \\
Evidence Strength & & & \\
Fingerprint Analysis X & -0.64 & 0.60 & 0.53 \\
Evidence Strength & & &
\end{tabular}

Note: DNA was used as the reference group for evidence type and weak evidence was used as the reference group for evidence strength.

$*_{p}<.05$

To test for differences between fingerprint analysis and eyewitness evidence, a separate logistic regression analysis was run with fingerprint analysis as the reference group. Table 6 summarizes the results of the analysis. The regression demonstrates that DNA evidence had no significant impact on juror verdicts compared to fingerprint analysis. Similarly, no interaction between DNA and evidence strength was found. A significant effect of eyewitness testimony 
was found, however. When all other variables are held constant, jurors' were $12.5(b=-2.53$, $\mathrm{OR}=.08$ ) times less likely to vote guilty than jurors in the fingerprint analysis condition. As when DNA was the reference group, a significant interaction between eyewitness testimony and evidence strength was found. This finding suggests that when all variables are held constant, jurors' are approximately 10 times $(b=2.29, \mathrm{OR}=9.84)$ more likely to vote guilty in the strong eyewitness condition as compared to the weak eyewitness condition.

Table 6

Summary of logistic regression predicting the impact of evidence type and evidence strength on dichotomous verdict $(N=282)$.
B
SE
OR

\section{Predictor}

\begin{tabular}{lccc}
\hline Eyewitness Testimony & $-2.53^{*}$ & .67 & .08 \\
DNA Evidence & .087 & .41 & 1.09 \\
Evidence Strength & .087 & .42 & 1.09 \\
Eyewitness Testimony X & $2.29^{*}$ & .79 & 9.84 \\
Evidence Strength & & & \\
DNA Evidence X Evidence & 0.64 & 0.60 & 1.89
\end{tabular}

Strength

Note: Fingerprint analysis was used as the reference group for evidence type and weak evidence was used as the reference group for evidence strength.

$* p<.05$

Hypothesis 2a predicted that participants who perceived television as more reflective of reality would be more critical of fingerprint analysis and eyewitness testimony than DNA evidence, resulting in fewer convictions when DNA was not present. To test hypothesis $2 \mathrm{a}$, a 
three-factor hierarchical logistic regression analysis was performed with evidence type, evidence strength, and perceived realism as the predictors and dichotomous verdict as the criterion. Evidence type and evidence strength are categorical variables, and were dummy coded using DNA evidence and weak evidence as the respective reference groups. Perceived realism is a continuous variable that was computed by summing the scores on Busselle's (2001) Television Perceived Realism scale. The scale demonstrated good internal consistency $(\alpha=.85)$. Table 7 summarizes the results of the hierarchical logistic regression analysis. Results of the regression analyses revealed significant main effects of evidence strength, evidence type, and perceived realism, though no significant interactions among the variables were found. This suggests that participants' perceptions of television realism do not affect their ratings of guilt differently depending on the strength of the evidence or the type of evidence presented. It was found that, excluding the impact of all other variables, jurors in the eyewitness testimony condition were 5 $(b=-1.63, O R=.196)$ times less likely to vote guilty than those in the DNA condition. Similarly, strong evidence increased odds of voting guilty $2.2(b=.79, \mathrm{OR}=2.204)$ times compared to weak evidence, and perceived realism was associated with a small increase $(b=.07, O R=1.072)$ in likelihood of voting guilty compared to those lower in perceived realism.

Table 7

Summary of logistic hierarchical regression analysis for predicting jurors' verdict outcomes $(N=275)$

Predictor B SE OR

\section{Step 1}

Eyewitness Testimony $-1.63 *$ .338 .196 
Fingerprint Analysis

Strong Evidence

Perceived Realism

\section{Step 2}

Eyewitness Testimony X Evidence

1.604

.824

4.974

Strength

Fingerprint Analysis X Evidence

$-.535$

.611

.382

Strength

Perceived Realism X Eyewitness

Testimony

Perceived Realism X Fingerprint

Analysis

Perceived Realism X Evidence

.009

.051

1.009

Strength

\section{Step 3}

Perceived Realism X Evidence

Strength X Eyewitness Testimony

Perceived Realism X Evidence

Strength X Fingerprint Analysis
.049

.082

.171

.108

1.186

Note: DNA and Weak Evidence were used as the reference groups for comparison. $* \mathrm{p}<.05$

To test for differences between fingerprint analysis and eyewitness evidence, a separate hierarchical logistic regression was conducted with fingerprint analysis as the reference group. 
Results of the analysis are summarized in Table 8. Results revealed main effects of perceived realism, evidence strength, and evidence type. It was found that, when all other variables are held constant, being in a strong evidence condition rendered jurors $2.2(\mathrm{OR}=2.204)$ times more likely to vote guilty than those in a weak evidence condition. Though no main effect or interaction with DNA evidence was apparent, jurors in the eyewitness testimony condition were $3.26(\mathrm{OR}=.326)$ times less likely to vote guilty than those in the fingerprint analysis condition. This analysis also revealed a significant interaction between evidence type and evidence strength. Specifically, jurors in the strong eyewitness condition were approximately $9(\mathrm{OR}=8.48)$ times more likely to vote guilty than those in the weak eyewitness condition.

Table 8

Summary of logistic hierarchical regression analysis for DNA evidence predicting jurors' verdict outcomes $(N=275)$

\begin{tabular}{lllll}
\hline Predictor & B & SE & OR
\end{tabular}

\section{Step 1}

Eyewitness Testimony

$-1.12 *$

.337

.326

DNA Evidence

.508

.312

1.662

Strong Evidence

$.79 *$

.266

2.204

Perceived Realism

$.070 *$

.023

1.072

Step 2

Eyewitness Testimony X Evidence

$2.139 *$

.818

8.488

Strength

DNA Evidence X Evidence Strength 
Perceived Realism X Eyewitness

Testimony

Perceived Realism X DNA Evidence

Perceived Realism X Evidence

Strength

\section{Step 3}

Perceived Realism X Evidence

Strength X Eyewitness Testimony

Perceived Realism X Evidence

$-.171$

.108

Strength X DNA Evidence

Note: Fingerprint analysis and weak evidence were used as the reference groups for comparison. ${ }^{*} \mathrm{p}<.05$

Finally, Hypothesis $2 \mathrm{~b}$ predicted that there would be a relationship between scores on the Perceived Realism scale and attitudes toward eyewitness testimony, fingerprint analysis, and DNA evidence. Correlation analyses were conducted between Busselle's (2001) Perceived realism scale and the Eyewitness Attitudes scale $(\alpha=.90)$, DNA Attitudes scale $(\alpha=.85)$, and Fingerprint Attitudes scale $(\alpha=.85)$. Results of correlation analyses using Pearson's ProductMoment Correlation $(r)$ revealed significant relationships between perceived realism and eyewitness attitudes $(r=.52, p<.01)$, DNA attitudes $(r=.42, p<.01)$ and fingerprint analysis attitudes $(r=.48, p<.01)$. The values indicated in Table 9 suggest a moderate, positive linear relationship between perceived realism and attitudes regarding each of the three evidence types presented in this study. 
Table 9

Eyewitness Fingerprint DNA Evidence Perceived

$\begin{array}{lll}\text { Testimony } & \text { Analysis } & \text { Realism }\end{array}$

Eyewitness $\quad 1.0$

Testimony

Fingerprint

$.49 *$

1.0

Analysis

DNA Evidence

$.32 *$

$.73 *$

1.0

Perceived

$.52 *$

$.48^{*}$

$.42 *$

1.0

Realism

Correlation matrix describing the association between perceived realism and attitudes toward different types of evidence.

${ }^{*}$ Correlations are significant at the $\mathrm{p}<.01$ level (two-tailed)

\section{DISCUSSION}

Contrary to previous research, the study presented here took a markedly different approach to examining the CSI-Effect. Prior research has predominantly focused on the relationship between a juror's expectations that DNA evidence be available in court as evidence and the quantity of crime-drama programming they consume (Podlas, 2006; Schweitzer \& Saks, 2007; Shelton et al., 2006). This project extends this line of research by studying the degree to which those consumers of television feel it accurately represents real life. In doing so, this 
research provides information regarding the relationship (or lack thereof) between perceived realism and perceptions of different evidence types in relation to the CSI-Effect.

\section{Perceptions of the Evidence}

This study supports previous findings regarding the influence of DNA evidence in impacting juror verdicts. Disregarding evidence strength, more guilty verdicts were rendered when DNA evidence was presented than when either eyewitness testimony or fingerprint analysis were introduced. This finding was expected, as it has been shown that jurors deem DNA evidence to be a highly infallible form of evidence and make verdict decisions in accordance with its presentation (Golding et al., 2008; Lieberman et al., 2008; Maeder, Ewanation, \& Monnink, under review).

DNA has been claimed to be the gold-standard against which scientific evidence is compared (Lieberman et al, 2008). On the other hand, very few studies have assessed juror perceptions of fingerprint analysis. The results of the analyses in this study found no significant differences in guilty verdicts between fingerprint and DNA evidence. Further, manipulations made to the strength of the fingerprint evidence were not associated with increases or decreases in juror ratings of guilt. A possible explanation for this finding could lie in the presentation of the fingerprint analysis rendered by the expert witness. The transcript utilized in this study presents fingerprint analysis evidence in a scientific manner. For example, the expert witness outlines in ample detail the process by which fingerprints are retrieved from crime scenes and entered into an Automated Fingerprint Identification System (AFIS). The witness then goes into detail of how the machine works and the process by which staff determine a match. It is possible that participants could not understand the language used by the expert witness. Drawing on Tversky and Kahneman's (1973) work on availability heuristics, participants may be evaluating the 
fingerprint evidence by relying on what they have learned about scientific evidence in past experiences. It is possible that participants inferred that the complex scientific language used was an indicator of the quality of the evidence, given previous associations between scientific language and objectivity.

It may also be the case that participants are evaluating the evidence based on their capacity or desire for cognitive activity (Petty \& Cacioppo, 1986). The Elaboration Likelihood Model (ELM) offers an explanation for how participants evaluate evidence. The theory proposes that evidence evaluation is moderated by each participant's Need for Cognition (NC) (Cacioppo \& Petty, 1982; Devine, 2012). It is suggested that those high in NC will take a systematic approach to evidence evaluation, examining the evidence more slowly and utilizing a greater degree of logic and rationality to parse out strengths and weaknesses. Conversely, Petty and Cacioppo (1986) suggest participants low in NC will evaluate evidence using a peripheral approach, which relies heavily on mental shortcuts and heuristics. Evaluation using a peripheral approach would likely lead participants to quickly assign a high probative value to the fingerprint evidence because of its similarity to other scientific language they have heard before. Though fingerprint analysis and DNA evidence rendered a statistically equal number of guilty verdicts, future studies should evaluate NC in an attempt to determine how jurors are evaluating evidence.

The language of the testimony could also explain why differences between strong and weak forms of fingerprint evidence were not found. The weak fingerprint analysis condition manipulated the credentials and competency of the expert, but the explanation of the fingerprint analysis collection and analysis process remained the same. It is possible that jurors deemed the scientific nature of the collection process to outweigh the poor credentials of the expert giving the testimony. Though this condition rendered fewer guilty verdicts than the DNA condition, it 
does warrant further investigation, as results still require a high degree of competency and subjectivity on behalf of the lab technician.

Finally, fewest guilty verdicts were rendered in the eyewitness testimony condition. Eyewitness testimony has been extensively studied. Markers known to increase or decrease a juror's confidence in an eyewitness are known and have been well supported (Berman \& Cutler, 1996; Brewer \& Burke, 2002; Wells, Lindsay \& Ferguson, 1976). It is not surprising, then, that a significant difference was found between the strong and weak eyewitness testimony conditions. Regardless of evidence strength, however, jurors in the eyewitness condition were less likely to vote guilty in comparison to the DNA and fingerprint analysis condition. This finding is consistent with previous research where the influence of different evidence types on juror verdicts has been assessed. In Lieberman and colleagues' (2008) Study 1, the researcher administered a survey that had participants rate the degree to which different types of evidence were influential in affecting their decision in a mock trial. Of the evidence types, DNA was rendered the most influential and compelling, outweighing both fingerprint analysis and eyewitness testimony. Similarly, when DNA or other scientific physical evidence and eyewitness testimony are presented in the same study, jurors consistently favour the scientific evidence (Skolnick \& Shaw, 2001).

\section{Perceived Realism and the CSI-Effect}

The logic and hypotheses of this study were developed on the premise that television is now the predominant information and knowledge provider for most people. This notion has led theorists to believe that television programming may be responsible for influencing people's knowledge and beliefs regarding various topics. This idea of influence is described within the realm of Cultivation Theory and is the result of work conducted by George Gerbner in the 1960's 
and 70's. A principle of Cultivation theory is the process of performing a method of analysis Gerbner (1976) coined as "Cultivation Analysis." Cultivation Analysis involves systematically analyzing a program or genre of shows for recurring themes and trends to determine if these themes are endorsed in the beliefs of heavy viewers. This was the approach taken by early researchers that failed to find any support for the CSI-Effect (Podlas, 2006; Schweitzer \& Saks, 2007; Shelton et al., 2006).

Because studying quantity has failed to provide support for the existence a CSI-Effect (Podlas, 2006; Schweitzer \& Saks, 2007; Shelton et al., 2006), new constructs need to be explored. This study does so by examining the degree to which people perceive television programming to be reflective of real life practices. This construct has been aptly termed "perceived realism". Research has studied perceived realism of television content across different genres and has shown that viewer attitudes regarding real life can reflect the ideas of a show's unrealistic depictions (Busselle, 2001; Quick, 2009; Taylor, 2005).

The results of this study do not provide support that the degree to which a juror perceives television programming to accurately reflect reality makes them more critical of particular types of evidence in a criminal trial. Based upon what is known about the strength of DNA evidence, it was felt that regardless of evidence strength, conviction rates in the DNA evidence condition would be greater in than the eyewitness testimony and fingerprint analysis conditions. This, as was mentioned earlier, was found. As it is the case that the CSI-Effect was theorized out of the failure of the prosecution to present DNA evidence, a closer look at juror verdicts when DNA evidence was not presented is especially important. It was posited that support of a CSI-Effect would be found if participants who scored higher on the Perceived Realism Scale were more critical of eyewitness testimony and fingerprint analysis than participants who scored lower on 
the scale. This would reflect the notion that those who perceive television to accurately represent real life practices would endorse the fictitious depictions those shows present. As previously stated, these depictions include an overly simplified DNA collection and analysis process. Therefore, those who score high in Perceived Realism would expect the presentation of DNA evidence and be critical of any other evidence types.

Though main effects of evidence type, evidence strength, and perceived realism were found, no significant interactions exist within the three variables. The hierarchical logistic regression analysis revealed that variability in juror verdicts could be explained by each of the three variables, but not significantly more by any combination of the three. Thus, jurors who scored higher in perceived realism were not any more critical of a particular type of evidence than jurors who scored lower in perceived realism. Jurors higher in perceived realism tended to have more positive attitudes toward each evidence type than did those lower in perceived realism and were more likely to render guilty verdicts, regardless of evidence type, though the effect of this finding was small. Future research should address this and explore perceived realism in relation to verdicts further. Content analyses regarding the rate at which crime-drama television shows convict or punish an accused should be investigated in relation to how those high in perceived realism render guilty verdicts. It may be the case that the increase in guilty verdicts found in this study among those high in perceived realism is a result of them reflecting the inordinate number of guilty verdicts they witness in crime-drama television shows. Ironically, it is the jurors who watch crime-drama programming that lawyers in many instances attempt to dismiss because they feel they will not convict without the presentation of DNA evidence.

The results of this study support the research conducted by Maeder and Corbett (2015). Those researchers examined an interaction between crime-drama television consumption and 
perceived reality of that programming and failed to find any direct or interactive effects on verdict outcomes. Though this study does not measure television consumption, it too failed to show that perceived realism impacts jurors' expectations that a particular type of evidence be presented at trial. That is, those high in perceived realism were just as likely to acquit a defendant when the prosecution failed to produce DNA or fingerprint evidence than those low in perceived realism. This study also supports Maeder and Corbett's (2015) findings that suggest participants who score higher in perceived realism show a positive association with attitudes regarding different types of evidence. It is possible that direct and indirect effects on verdict outcomes may be found and associated with attitudes regarding different evidence types, though further research is required.

Future research should continue to study perceived realism as an impactful variable that may bias the knowledge a juror relies upon when assessing different types of evidence. Though perceived realism may not act directly upon verdict outcomes, research has shown that it may be indirectly associated with verdict outcomes by shaping attitudes regarding different evidence types (Maeder \& Corbett, 2015).

It may also be the case that studying the perceived realism of television content is now too narrow of an approach. That is, television is only one of many mediums that people interact with on a daily basis. It is suggested that studies should begin to incorporate people's interaction with not only television, but news media and internet content. This is problematic and considerations of how these messages are cultivated should be made. From the time cultivation theory was put forth in the 70's, television and media content have changed dramatically. Gerbner and Gross (1976) were theorizing at a time when television content was new and people had relatively little options regarding programming (by today's standards). Today however, 
consumers are more able to make their own choices regarding the type of media they consume. Future research on perceived realism should take this notion into account and design studies accordingly. For instance, rather than provide a list of programs that participants may or may not watch, it may be wise to allow participants to indicate the programs they watch and rate the degree they feel those program reflects reality. Further, assessing the source and quantity of media one consumes may be an important variable. Rather than focusing solely on television, future studies should capture how much and what type of media one consumes from radio, newspapers, and internet sources.

Future research should also begin to study perceived realism and the CSI-effect by utilizing jury deliberation. Though deliberation studies are costly and organizationally difficult to perform, their inquiry is important as it would increase a study's ecological validity. It may be found that a few members within a jury may endorse CSI-effect beliefs and influence the rest of the jury. Conversely, these misguided jurors may raise arguments or points that other jury members may not have thought of upon hearing the evidence of the case, such as why the prosecution failed to present DNA evidence. As few effects have been found in CSI-Effect research, it may be that traditional research does not delve into the effect of influence that may occur in a jury deliberation.

\section{Limitations}

Though the study here was conducted in a structure that follows a great deal of jury research, limitations in its design are apparent. First, this study utilizes a case summary and trial transcript rather than more ecologically valid stimuli, such as video-taped trials or live mock trials. Though this is the case, research has suggested that mode of presentation has little impact on study outcomes (Bornstein, 1999; Pezdek, Avila-Mora, \& Sperry, 2010). 
Second, this study was conducted using an online sample of jury-eligible, American citizens recruited through a platform called Mechanical Turk (MTurk). Potential problems with this sample are simply that researchers are not on site to clarify any inquiries participants may have regarding the transcript or questionnaire. Further, it may be the case that participants do not fully pay attention to the stimulus materials and simply click through the questionnaire in an attempt to finish the survey as quickly as possible. This study rectified this potential problem by embedding attention checks within the questionnaire. These attention checks are designed to ensure participants read and paid attention to the trial summary and court transcript, as well as weed out participants who are merely clicking through the questionnaire. In total, only 12 respondents were excluded for analysis due to their failing attention checks. Aside from the aforementioned methodological issues, MTurk samples have been shown to be as representative of American samples as traditional subject pools (Paolacci, Chandler, \& Ipeirotis, 2010). As such, many social scientists have now adopted the use of MTurk and have obtained results that rival traditional methods (Bates \& Lanza, 2013).

\section{CONCLUSION}

To conclude, this research failed to demonstrate a relationship between perceived realism and juror verdicts in a manner that supports the hypothesized CSI-effect. Though this is the case, the results of this study are still important. First, this study enhanced what is known regarding juror perceptions of different types of evidence - namely, DNA, fingerprint analysis and eyewitness testimony. It demonstrated that jurors are more willing to convict a defendant if DNA or fingerprint evidence is presented than if eyewitness testimony is the primary evidence. Further, it provides support that evidence strength makes only a negligible difference on conviction rates if DNA or fingerprint analysis evidence is provided. This study's examination of 
fingerprint analysis revealed that it is as compelling as DNA evidence in affecting ratings of guilt. This finding is important, as little attention has been given specifically to fingerprint evidence.

Second, this study reveals more about what is known about the CSI-Effect. Though jurors may be acquiring their knowledge about crime and scientific evidence collection and analysis from television, this study failed to demonstrate that this impacts their expectation that the prosecution bring forth DNA evidence. Investigation into the CSI-Effect should continue, as understanding how jurors are influenced by extralegal factors is an important consideration in the process of criminal trials. 


\section{References}

Bates, J. A., \& Lanza, B. A. (2013). Conducting psychology student research via the Mechanical Turk crowdsourcing service. North American Journal of Psychology, 15(2), 385.

Retrieved from

https://proxy.library.carleton.ca/http://go.galegroup.com/ps/i.do?id=GALE\%7CA331348 $\underline{553 \& \mathrm{v}=2.1 \& \mathrm{u}=\mathrm{ocul} \text { carleton } \& \mathrm{it}=\mathrm{r} \& \mathrm{p}=\mathrm{AONE} \& \mathrm{sw}=\mathrm{w} \& \mathrm{asid}=5712 \mathrm{fd} 9 \mathrm{a} 2 \mathrm{bdea} 7 \mathrm{a} 1 \mathrm{e} 5 \mathrm{eb} 86 \mathrm{e}}$ $\underline{56 \mathrm{de} 4648 \mathrm{c}}$

Berman, G. L., \& Cutler, B. L. (1996). Effects of inconsistencies in eyewitness testimony on mock-juror decision making. Journal of Applied Psychology, 81, 170-177.

Besley, J. C., \& Shanahan, J. (2005). Media attention and exposure in relation to sup- port for agricultural biotechnology. Science Communication, 26, 347-367.

Brewer, N., Burke, A. (2002). Effects of testimonial inconsistencies and eyewitness confidence on mock-juror judgements. Law and Human Behaviour, 26(3) 353- 364.

Brewer, R. P., \& Ley, L. B. (2010). Media use and public perceptions of DNA evidence. Science Communication, 32(1), 93-117.

Busselle, R. W. (2001). Television exposure, perceived realism, and exemplar accessibility in the social judgment process. Media Psychology, 3, 43-67.

Busselle, R., \& Bilandzic, H. (2012). Cultivation and the perceived realism of stories. In Morgan, M., Shanahan, J., \& Signorielli, N. Living with television now: advances in cultivation theory \& research. (168-186). New York: Peter Lang.

Cable News Network. (2005). Blake found not guilty in wife's killing. Retrieved from: 


\section{http://www.cnn.com/2005/LAW/03/16/blake.case/index.html?iref=newssearch}

Cacioppo, J. T., \& Petty, R.E. (1982). The need for cognition. Journal of Personality and Social Psychology, 42, 116-131.

Cole, A. S., \& Dioso-Villa, R. (2007). CSI and its effects: media, juries, and the burden of proof. New England Law Review, 41, 435-470.

Cole, A. S., \& Dioso-Villa, R. (2009). Investigating the 'CSI Effect' effect: media and litigation crisis in criminal law. Stanford Law Review, 61, 1335-1373.

Dale, W. M., Greenspan, O., \& Orokos, D. (2006). DNA forensics: Expanding uses and information sharing. Sacramento, CA: SEARCH, The National Consortium for Justice Information and Statistics.

Devine, J. D. (2012). Jury decision making: The state of the science. New York: New York University Press,

Gerbner, G. (1963). A theory of communication and its implications for teaching. In The Nature of Teaching: Implications for the Education of Teachers (pp.33-46). Milwaukee: University of Wisconsin-Milwaukee, School of Education.

Gerbner, G., \& Gross, L. (1976). Living with television: The violence profile. Journal of Communication, 26, 173-199.

Gerbner, G., Gross, L., Morgan, M., \& Signorielli, N. (1981). Scientists on the TV screen. Culture and Society, 18, 41-44.

Gerbner, G., Gross, L., Morgan, M., \& Signorielli, N. (1994). Growing up with television: The cultivation perspective. In J. Bryant \& D. Zillmann (Eds.), Media effects. Advances in 
theory and research (pp. 17-41). Hillsdale, NJ: Lawrence Erlbaum Associates.

Golding, M. J., Stewart, L. T., Yozwiak, A. J., Djadali, Y., \& Sanchez, P. R. (2000). The impact of DNA evidence in a child sexual assault trial. Child Maltreatment, 5(4), 373-383.

Goodman, J. (1992). Jurors' comprehension and assessment of probabilistic evidence. The American Journal of Trial Advocacy, 16, 361-389.

Goodman-Delahunty, J., \& Tait, D. (2006). DNA and the changing face of justice. Australian Journal of Forensic Sciences, 38, 97-106.

Hayes, R. M., \& Levett, L. M. (2012). Community members' perceptions of the CSI effect. American Journal of Criminal Justice, 38(2), 216-235.

Houck, M. (2006). CSI: Reality. Scientific American, 295, 84-89. Retrieved from BusinessSource Premier database.

Koehler, J. J. (2011). If the shoe fits they might acquit: The value of forensic science testimony. Journal of Empirical Legal Studies, 8, 21-48.

Law Centre. (2005). Blake found not guilty in wife's killing. Retrieved from http://www.cnn.com/2005/LAW/03/16/blake.case/index.html?iref=newssearch

Ley, L. B., Jankowski, N., \& Brewer, R. P. (2012). Investigating CSI: Portrayals of DNA testing on a forensic crime show and their potential effects. Public Understandings of Science, 21(1), 51-67.

Lieberman, D. J., Carrell, A. C., Miethe, D. T., \& Krauss, A. D. (2008). Gold Versus Platinum: Do jurors recognize the superiority and limitations of DNA evidence compared to other types of forensic evidence? Psychology, Public Policy, and Law, 14(1), 27-62. 
Maeder, E.M., \& Corbett. (2015). Beyond frequency: Perceived realism and the CSI-effect. Canadian Journal of Criminology and Criminal Justice, 57(1), 83-114.

Maeder, E.M., Ewanation, L., \& Monnink, J. (under review). Jurors' perceptions of evidence: The relative influence of DNA and eyewitness testimony when presented by opposing parties. Manuscript under review at the Journal of Police and Criminal Psychology.

Mancini, D. (2011). The CSI Effect reconsidered: Is it moderated by need for cognition? North American Journal of Psychology, 13(1) 155-174.

McQuiston-Surett, D., \& Saks, M., J. (2009). The testimony of forensic evidence science: What expert witnesses say and what factfinders hear. Law and Human Behaviour, 33(5), 436453.

Morgan, M., Shanahan, J., \& Signorielle, N. (2012). Living with television now: Advances in cultivation theory \& research. New York: Peter Lang.

Nisbet, M. C., Scheufele, D. A., Shanahan, J., Moy, P., Brossard, D., \& Lewenstein, B.V. (2002). Knowledge, reservation, or promise? A media effects model for public perceptions of science and technology. Communication Research, 29, 584-608.

Paolacci, Gabriele. (2010). Running experiments on Amazon Mechanical Turk. Judgment and decision making. (5)5. p.411 - 419.

Petty, R. E., \& Cacioppo, J.T. (1986). Communication and persuasion: Central and peripheral routes to attitude change. New York: Springer-Verlag.

Pezdek, K., Avila-Mora, E., \& Sperry, K. (2010). Does trial presentation medium matter in jury 
simulation research? Evaluating the effectiveness of eyewitness expert testimony. Applied Cognitive Psychology, 24(5), 673-690.

Podlas, K. (2006). The CSI effect: Exposing the media myth. Fordham Intellectual Property, Media, \& Entertainment Law Journal, 16, 430-465.

Potter, W. J. (1986). Perceived reality and the cultivation hypothesis. Journal of Broadcasting \& Electric Media, 32, 23-41.

Prentice, D., \& Gerrig, R. (1999). Exploring the boundary between fiction and reality. In S. Chaiken \& Y. Trope (Eds.), Dual-process theories in social psychology (pp. 529-546). New York: Guilford.

Quick, B. L. (2009). The effects of viewing Grey's Anatomy on perceptions of doctors and patient satisfaction. Journal of Broadcasting \& Electronic Media, 53, 38-55.

Roane, K. (2005). The CSI effect. U.S. News and World Report, 138, 48-54.

Saks, M. J., \& Koehler, J. J. (2005). The coming paradigm shift in forensic identification science. Science, 309, 892-895.

Schklar, J., \& Diamond, S., S. (1999). Juror reaction to DNA evidence: Errors and expectancies. Law and Human Behaviour, 23(2), 159-184.

Schweitzer, J. N., \& Saks, J. M. (2007). The CSI effect: Popular Fiction about forensic science affects the public's expectation about real forensic science. Jurimetrics, 47, 357-364.

Shelton, E. D., Kim, S. Y., \& Barak, G. (2006). A study of juror expectations and demands concerning scientific evidence: does the "CSI-Effect" exist? Vanderbilt Journal of 
Entertainment and Technology Law, 9, 331-368.

Shrum, L. J., Wyer, R. S., \& O’Guinn, T. C. (1998). The effects of television consumption on social perceptions: The use of priming procedures to investigate psychological processes. Journal of Consumer Research, 24, 447-458.

Skolnick, P. \& Shaw, I. J. (2001). A comparison of eyewitness and physical evidence on mockjuror decision making. Criminal Justice and Behaviour, 28(5), 614-630.

Smith, L. L., \& Bull, R. (2012). Identifying and measuring juror pre-trial bias for forensic evidence: development and validation of the Forensic Evidence Evaluation Bias Scale. Psychology, Crime \& Law, 18(9), 797-815.

Taylor, L. D. (2005). Effects of visual and verbal sexual television content and perceived realism on attitudes and beliefs. The Journal of Sex Research, 42, 130-137.

Thompson, W. C., \& Schumann, E. (1987). Interpretation of statistical evidence in criminal trials: The prosecutor's fallacy and the defense attorney's fallacy. Law and Human Behavior, 11, 167-187.

Tyler, R. T. (2006). Viewing CSI and the threshold of guilt: Managing truth and justice in reality and fiction. The Yale Law Journal, 115, 1050-1085.

Tversky, A., \& Kahneman, D. (1973). Availability: A heuristic for judging frequency and probability. Cognitive Psychology, 5, 207-232.

Wells, G. L., Lindsay, R. C. L., \& Ferguson, T. J. (1979). Accuracy, confidence, and juror perceptions in eyewitness identification. Journal of Applied Psychology, 64, 440-448. 


\title{
Appendix A: Trial Transcripts
}

\author{
Condition 1: Prosecution Strong DNA Evidence vs. Defence Alibi Evidence
}

In Case No. CR98R03168-00, Steven Murphy is accused of second-degree murder. On the night of September 8, 2013, the victim (Paul Thompson) was assaulted while running in a park downtown.

At approximately 11:45pm, the District Attorney's (DA) office alleges that Steven Murphy sat on a bench in a darker section of the park holding a newspaper in front of his face. According to the DA's story, when Murphy saw Paul Thompson running alone, he stood up and followed him. As Thompson bent down to tie his shoe, the DA claims that Murphy grabbed him from behind, covering his mouth. When Thompson started putting up a fight, his attacker pulled out a large knife and held it to his throat. It is believed that Murphy was interested in money, but Thompson had not carried his wallet with him on his run. As Thompson tried to fight back, he scratched his attacker with his keys, leaving some of the assailant's blood at the crime scene. After several minutes of fighting, the attacker finally cut deeply into Thompson's stomach. When Thompson fell to the ground, the assailant removed his watch, running shoes and MP3 player before fleeing the scene.

At Approximately 2:00 a.m. on September 9, police officer Mark Riley noticed a suspicious young, white male anxiously pacing outside of a 24-hour diner near the park. The man appeared to have a bloodstain on his t-shirt. Officer Riley questioned the individual, asking if he needed help. The man fidgeted, stared at the ground and said he worked as a cook. His coworker had cut himself earlier in the night. The man said everything was fine now, and he was just on a smoke break. The next morning, when Officer Riley heard of the murder, he thought of the man's somewhat odd behavior and encouraged the detectives to look for him.

Police officers found Steven Murphy in the park the next day and brought him in for questioning. Officers asked Murphy where he had been the night before, and he said he was at work. Prior to that, he had been at the park, but he claimed he left the park shortly after dark and walked around downtown before starting his shift.

The Defence contends that the police charged Steven Murphy with the crime because they were incapable of conducting a more thorough investigation. The Defence alleges that the DA's office arrested the first suspect they found as a way to appease angry citizens who were concerned that such a violent act could take place in their safe, neighborhood park. Further, the Defence plans to bring forth testimony from a coworker of Steven Murphy who can speak to the timeframe Murphy was at work the night the murder took place. The coworker's name is Andrew Baldwin; he has been working at the restaurant for two years and has proven to be a responsible and dependable employee.

Later, Officer Mark Riley asked Steven Murphy to voluntarily submit a sample of his DNA for testing. After some initial hesitation citing privacy concerns, Murphy obliged, and a swab of his cheek cells were taken and submitted to CellCode Laboratories, Inc. for identification. Blood samples from the crime scene and from Paul Thompson were also submitted to CellCode. At the 
trial, lab technician Frank Miller presented the evidence for the prosecution.

\section{Below is the transcript from court records of Frank Miller's testimony:}

District Attorney: The prosecution calls Mr. Frank Miller to the stand.

DA: Will you please state your name and occupation for the court?

Expert: My name is Frank Miller, and I am a forensic lab technician at CellCode Laboratories.

DA: Mr. Miller, what is your educational background and current area of work at CellCode?

Expert: I went to Princeton University for my undergraduate education, where I studied molecular biology. Immediately upon graduation, I was hired to be a part of CellCode's junior technician program, where I was trained in forensic science techniques with an emphasis on DNA sequencing, including restriction fragment length polymorphism, short tandem repeat sequencing and polymerase chain reaction amplification. I have been working at CellCode for seven years, and I now serve as the supervisor of the DNA Identification Unit.

DA: What are your duties as supervisor?

Expert: I oversee all of the DNA identifications made at CellCode. I ensure that our lab facilities are clean and free of any contaminants. I am also the coordinator of our unit for the proficiency tests run by the American Society of Crime Lab Directors (ASCLD). These tests help our lab acquire accreditation through the Council to certify that we use appropriate industry standards in our procedures.

DA: How many labs are accredited by the Council?

Expert: Out of all the labs in America only $25 \%$ are accredited so it really is quite an honor for CellCode to be among that group. It means that we are doing our job well.

DA: In your years at CellCode, how many DNA identifications have you made using the current technique?

Expert: Oh gosh, far too many to count. Although, I haven't been doing as many myself personally since I took over more management roles.

DA: Did you examine Mr. Murphy's DNA sample?

Expert: Yes, sir. One of my unit members was really backed up one day, and it was his wife's birthday, so I ended up starting work on this particular sample's examination.

DA: Could you tell the court a little bit about the procedures you use to determine whether or 
not there is a match between the victim and the defendant?

Expert: Certainly. Today, the most common type of DNA testing is called polymerase chain reaction testing or PCR for short. PCR is great because we can use it even if we only have small samples of DNA. At CellCode, we use the AmpFISTR Identifiler PCR Amplification Kit, which simultaneously amplifies 15 short tandem repeat locations in addition to the Amelogenin genderdetermining marker in a single, robust PCR. This test gives us information about the thirteen standard loci sites that are required by the FBI.

DA: So what does that mean to someone who does not understand science?

Expert: Well, we do not sequence all of the genes or information coded in our genome. Instead, we look at these thirteen specific sites that are known to vary widely among the population. These sites actually don't code for anything so they are very different from looking at, say, whether someone is male or female, tall or short, blonde haired or black haired. These thirteen locations have repeated codes, and the number of codes differs among individuals. So what we're really looking at is how these numbers differ. If you look at my picture, here, you can see how this works.

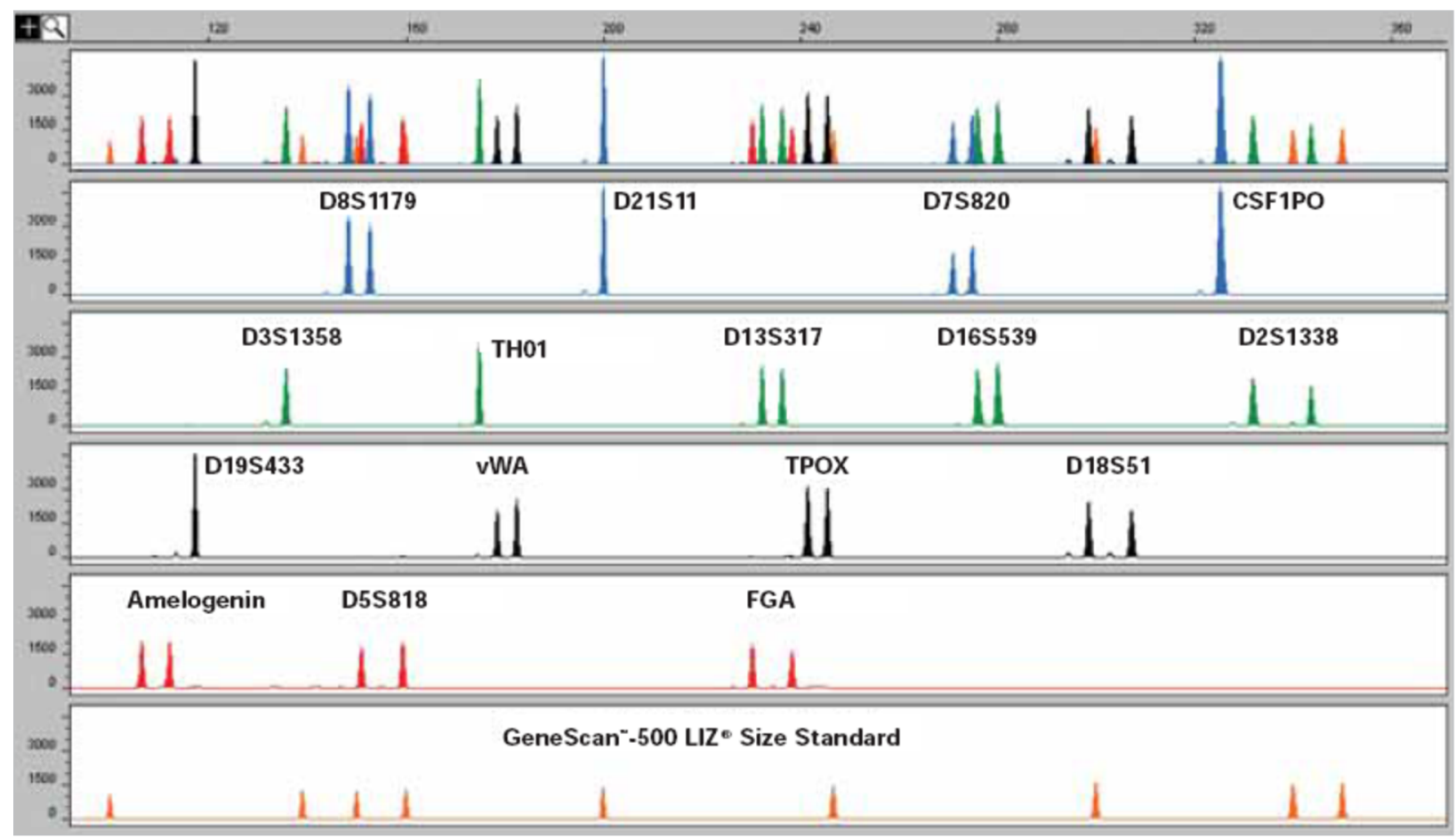

Look at the second line. D8S1 179 is the name of the location. That doesn't matter very much. It's just like your home address. What matters is how tall those two peaks are right there. If the defendant's DNA has different peak heights than the crime scene DNA, they are not a match.

DA: And was there a match between the defendant and the crime scene DNA in this case? Expert: Yes, there was a match. 
DA: Is it possible this match was caused by a degradation of the blood sample?

Expert: No, it is highly unlikely that any such damage exists in this case, and it is rare for damage to make the DNA look precisely like that of another person.

DA: What does it mean to find a DNA "match"?

Expert: According to natural statistical variances, there is only a $.00005 \%$ chance that this defendant is not the same man whose DNA was found at the crime scene with your victim.

DA: $.00005 \%$ ? That is not a very large percentage.

Expert: No, it is not. It is nearly impossible that anyone other than this defendant left his blood at the crime scene.

DA: Where does that number come from?

Expert: It is based on statistics from our database of various samples of DNA. These samples tell us how frequently certain traits occur in varying racial or geographic populations.

DA: So according to your analysis, Mr. Murphy's blood is the same as the blood found at the crime scene?

Expert: Yes, that is correct.

DA: Thank you, Mr. Miller. No further questions.

Next, the Defence attorney began to question the expert, Mr. Miller.

Defence: So with all this advanced technology at CellCode, there is no possible way that two people can have the same DNA identification profile, right?

Expert: Well, no, that's not quite true.

Defence: Why not? I thought each one of us had our own unique DNA fingerprint.

Expert: Because, like I said earlier, we do not sequence the entire genome so we cannot see all of the differences between people. That's why we can only give a statistic. But I can say that there is a very very small chance that the blood belongs to anyone other than the defendant.

Defence: The chance is $.00005 \%$, right?

Expert: That is correct.

Defence: Well, if I'm doing my math right, that converts to a 1 in 2 million chance that someone other than my client left his DNA at the crime scene, correct? 
Expert: Uh, yes, I suppose you could look at it like that.

Defence: This city alone has nearly 2.8 million citizens. So it is possible that someone other than my client was the donor of the blood left at the crime scene and thus was the assailant.

Expert: Yes, there is a small possibility that the blood could have belonged to someone else, but the person with that precise combination would have had to be in this city, near the crime scene on that night. That would be quite a coincidence.

Defence: Nevertheless, it's possible. Now, isn't it true that some people are wrongly convicted because of DNA evidence?

Expert: Well, that's very rare, especially at CellCode. Many people are released from prison based on our DNA tests that proved other types of evidence to be wrong. DNA is a very reliable means of identification.

Defence: But it is true. Some people have been wrongly convicted because of faulty DNA evidence.

Expert: Yes, I suppose that is true, but I have never been involved with any such case.

Defence: Isn't it true that DNA samples can easily become contaminated because of things as common as humidity, sweat, oxygen or breath?

Expert: Yes, that's true, and contamination can be a problem, but at CellCode, we are very careful to maintain clean facilities. All of our storage areas are carefully monitored with computer-regulated humidifiers and thermostats. We have an excellent record in our proficiency tests, and contamination problems are rare.

Defence: What about the police handling of the DNA? You can't monitor the DNA from the time it left the attacker to its arrival in your lab. Couldn't the police have contaminated the evidence accidentally or intentionally?

Expert: Well, yes, police contamination is possible, but in this case, the detectives who collected the blood samples were unaware of any suspect in the case, and it would have been difficult to tamper with the blood. These samples were, in fact, some of the best I've seen.

Defence: When the police submitted the samples to you, were you aware of which sample came from whom?

Expert: Yes, I did know which sample was which. That is necessary to keep things organized in the lab, but I also had a control sample to run in comparison with the known samples from the crime scene, victim and suspect.

Defence: Did you know how the police found the suspect? 
Expert: I heard from the detectives they saw him near the crime scene and picked him up for questioning.

Defence: Couldn't your knowledge of the police's strong suspicion of this suspect have affected your ability to run an unbiased experiment on these samples?

Expert: Listen, sir, this is a very high profile case, and I want the police to find the murderer just as much as everyone else in this city. I am concerned about the violence in the park, but that concern would never affect my work. This is science, after all. It is entirely factual.

Defence: Entirely factual? So you're telling me there is no possible way for your own opinion to affect your judgment of the results?

Expert: No, sir.

Defence: Have you ever testified differently?

Expert: No, sir.

Defence: Well, several months ago, Mr. Miller, I asked you some questions in a deposition, and you mentioned something about a "match window." You said that the heights of the peaks don't have to match up perfectly. Thus, it would appear to me that you could claim these heights are a match, when they are not. Your personal opinion about the guilt of this suspect could affect how you judge these peaks' heights.

Expert: No, my opinion would not affect my results. Like I said before, this is factual. Given the natural variants in the way the blood runs through the gels, we compare the peaks to the best of our ability, and when you declare a match, they can be slightly off. But I have been in this business for seven years, and I have never declared a match when one did not exist. These peaks are very easy to distinguish, and there was a match between the defendant and the blood at the crime scene.

Defence: But all of the peaks were not exactly the same size, were they?

Expert: Almost all of the peaks were exactly the same size, and the rest were clearly within the match window, obviously indicating a match.

Defence: The peaks were not exactly the same size, were they?

Expert: No, not exactly, they were -

Defence: Your bias for the police story could have caused you to believe these peaks were close enough for a match when they were not. No further questions.

Later, the Defence asked Andrew Baldwin to testify in the Trial against Steven Murphy to corroborate the whereabouts of the defendant during the time of the offence. Baldwin obliged and was a key witness for the Defence in the case against Steven Murphy. 
Below is the transcript from Court Records of Baldwin's Testimony:

Defence Attorney: The Defence calls Mr. Andrew Baldwin to the stand.

Defence: Will you please state your name and occupation for the court?

Baldwin: My name is Andrew Baldwin, I'm a cook at Ray's Diner, where I work primarily the overnight shift.

Defence: What exactly do your duties include while working at the restaurant?

Baldwin: Honestly I mostly flip burgers and eggs. I'm a line cook so the job is pretty simple, pretty much anyone could do it. Outside of cooking I make sure the kitchen is kept clean and that all the prep is done for the morning shift.

Defence: How long have you worked at Ray's Diner?

Baldwin: About 2 years.

Defence: And how long have you been working with Steven Murphy?

Baldwin: About 6 months.

Defence: You said you work the overnight shift? What hours does your shift cover?

Baldwin: I work Wednesday through Sunday from 11pm-7am.

Defence: On September 8, did you work with Steven Murphy?

Baldwin: Yeah, he comes in during the overnight rush when the bars let out to wash dishes. It was a really busy night and we needed his help.

Defence: So he was at work during his scheduled hours for the night?

Baldwin: Yes he was.

Defence: Was Steven Murphy acting funny, or suspicious during his shift on the night in question?

Baldwin: No not really, at least not in any way I could tell.

Defence: Could you see a knife or any other weapon on his person?

Baldwin: No (chuckles). Just the knives he was washing for the restaurant. 
Defence: What time did Steven Murphy leave work in the morning?

Baldwin: He left at around 4:30am.

Defence: Are you sure of that?

Baldwin: Yes.

Defence: Can you state for the court the exact timeframe Steven Murphy was at Ray's Diner during the early morning hours of September 9, 2013?

Baldwin: Steven Murphy was working and at the restaurant from 12:00am to 5:00am

Defence: Thank you, Mr. Baldwin. No further questions.

Next, the District Attorney began to question the witness, Andrew Baldwin:

DA: Mr. Baldwin, can you state again for the court how long you have been working at Ray's Diner?

Baldwin: Two years now.

DA: Aside from cooking and doing prep, do you have any other responsibilities at the diner? Say managerial tasks, payroll, accounting, time sheets for example?

Baldwin: No, I'm just an overnight cook. The daytime kitchen manager deals with all that stuff.

DA: So it is not your responsibility per se to keep people accountable to showing up on time for work or disciplining for any wrongdoings?

Baldwin: No, not directly, but I will voice my opinion to the day manager if someone's late and it messes up my service for the night.

DA: Has Stephen Murphy ever missed any shifts or shown up late?

Baldwin: Not that I can recall. I don't think he's ever missed any shifts, may have shown up late a couple times, but I can't be too sure about that.

DA: Is that because it's not your responsibility to keep track of coworkers' tardiness?

Baldwin: I guess so, he's just a dishwasher so I work closely with him but generally he goes about his job and I go about mine.

DA: So you can't say with certainty that Stephen Murphy was at work at the exact time he was supposed to be? 
Baldwin: No I guess not, but I know he was there around the time he was scheduled to start, which was 12:00am.

DA: I have no further questions. 


\section{Appendix B: Juror Instructions}

The defendant has pleaded not guilty to the charge. The fact that a criminal charge has been filed against the defendant is not evidence that the charge is true. You must not be biased against the defendant just because he has been arrested, charged with a crime, or brought to trial.

A defendant in a criminal case is presumed to be innocent. This presumption requires that the People prove a defendant guilty beyond a reasonable doubt. Whenever I tell you the People must prove something, I mean they must prove it beyond a reasonable doubt [unless I specifically tell you otherwise].

Proof beyond a reasonable doubt is proof that leaves you with an abiding conviction that the charge is true. The evidence need not eliminate all possible doubt because everything in life is open to some possible or imaginary doubt.

In deciding whether the People have proved their case beyond a reasonable doubt, you must impartially compare and consider all the evidence that was received throughout the entire trial. Unless the evidence proves the defendant guilty beyond a reasonable doubt, he is entitled to an acquittal and you must find him not guilty.

\section{Murder Charge}

\section{A. Felony Murder: Second Degree- Defendant Allegedly Committed Fatal Act}

The defendant is charged in Count 541A with murder, under a theory of felony murder.

To prove that the defendant is guilty of second degree murder under this theory, the People must prove that:

* The defendant committed [or attempted to commit] the murder of Paul Thompson

* The defendant intended to commit the murder of Paul Thompson 
3. The defendant did an act that caused the death of another person.

A person may be guilty of felony murder even if the killing was unintentional, accidental, or negligent.

[The defendant must have (intended to commit)[or] aided and abetted[,] [or] been a member of a conspiracy to commit) the (felony/ felonies) of Felony Murder before or at the time of the act causing the death.]

[It is not required that the person die immediately, as long as the act causing death occurred while the defendant was committing the (felony/ felonies).]

An act causes death if the death is the direct, natural, and probable consequence of the act and the death would not have happened without the act. A natural and probable consequence is one that a reasonable person would know is likely to happen if nothing unusual intervenes. In deciding whether a consequence is natural and probable, consider all the circumstances established by the evidence.

[There may be more than one cause of death. An act causes death only if it is a substantial factor in causing the death. A substantial factor is more than a trivial or remote factor. However, it does not need to be the only factor that causes the death.]

[It is not required that the person killed be the (victim/intended victim) of the (felony/felonies).]

[It is not required that the defendant be present when the act causing the death occurs.] 


\section{Appendix C: Juror Questionnaire}

INSTRUCTIONS: Please respond to the following items with regards to the $2^{\text {nd }}$ degree murder charge against the defendant.

1. How do you find the defendant, Steven Murphy?

GUILTY

NOT GUILTY 


\section{Appendix D: Attitude Towards Evidence Scale}

Carefully read each of the following scale items carefully and circle the number that best reflects how much you agree or disagree.

Use the following scale to answer each question:

$1=$ I very strongly DISAGREE with the statement

$10=$ I very strongly AGREE with the statement

2. Eyewitness testimony is an important part of most trials

$$
\begin{array}{llllllllll}
1 & 2 & 3 & 4 & 5 & 6 & 7 & 8 & 9 & 10
\end{array}
$$

3. Eyewitnesses are reliable witnesses

$\begin{array}{llllllllll}1 & 2 & 3 & 4 & 5 & 6 & 7 & 8 & 9 & 10\end{array}$

4. Eyewitness testimony provides crucial evidence in trials

$\begin{array}{llllllllll}1 & 2 & 3 & 4 & 5 & 6 & 7 & 8 & 9 & 10\end{array}$

5. Eyewitnesses frequently misidentify innocent people just because they seem familiar

$$
\begin{array}{llllllllll}
1 & 2 & 3 & 4 & 5 & 6 & 7 & 8 & 9 & 10
\end{array}
$$

6. Eyewitnesses generally give accurate testimony in trials

$$
\begin{array}{llllllllll}
1 & 2 & 3 & 4 & 5 & 6 & 7 & 8 & 9 & 10
\end{array}
$$

7. The strongest evidence is provided by eyewitnesses

$$
\begin{array}{llllllllll}
1 & 2 & 3 & 4 & 5 & 6 & 7 & 8 & 9 & 10
\end{array}
$$

8. Eyewitnesses can usually be believed

$$
\begin{array}{llllllllll}
1 & 2 & 3 & 4 & 5 & 6 & 7 & 8 & 9 & 10
\end{array}
$$

9. Eyewitness testimony is more like fact than opinion

$$
\begin{array}{llllllllll}
1 & 2 & 3 & 4 & 5 & 6 & 7 & 8 & 9 & 10
\end{array}
$$

10. Eyewitnesses generally do not give accurate descriptions

$\begin{array}{llllllllll}1 & 2 & 3 & 4 & 5 & 6 & 7 & 8 & 9 & 10\end{array}$

Please read the following statements and respond according to how much you agree or 


\section{disagree with the position presented.}

Use the following scale to answer each question:

$1=$ I very strongly DISAGREE with the statement

$10=$ I very strongly AGREE with the statement

11. DNA is the most reliable type of physical evidence we have today.

$$
\begin{array}{llllllllll}
1 & 2 & 3 & 4 & 5 & 6 & 7 & 8 & 9 & 10
\end{array}
$$

12. If the fingerprints taken from a crime scene match those of the defendant's, the defendant is guilty.

$$
\begin{array}{llllllllll}
1 & 2 & 3 & 4 & 5 & 6 & 7 & 8 & 9 & 10
\end{array}
$$

13. I would convict a defendant if the only evidence against him were fingerprints.

$\begin{array}{llllllllll}1 & 2 & 3 & 4 & 5 & 6 & 7 & 8 & 9 & 10\end{array}$

14. If an offender does not wear gloves, his fingerprints can easily be found at a crime scene.

$\begin{array}{llllllllll}1 & 2 & 3 & 4 & 5 & 6 & 7 & 8 & 9 & 10\end{array}$

15. If detectives obtain a blood sample from a crime scene, they can easily compare that DNA to a suspect's DNA.

$\begin{array}{llllllllll}1 & 2 & 3 & 4 & 5 & 6 & 7 & 8 & 9 & 10\end{array}$

16. I would convict a defendant if the only evidence against him was DNA.

$\begin{array}{llllllllll}1 & 2 & 3 & 4 & 5 & 6 & 7 & 8 & 9 & 10\end{array}$

17. If detectives lift fingerprints from a crime scene, they can easily compare them to a suspect's prints.

$$
\begin{array}{llllllllll}
1 & 2 & 3 & 4 & 5 & 6 & 7 & 8 & 9 & 10
\end{array}
$$

18. Fingerprints are some of the best forensic evidence that can be collected.

$\begin{array}{llllllllll}1 & 2 & 3 & 4 & 5 & 6 & 7 & 8 & 9 & 10\end{array}$

19. If a defendant's DNA matches DNA left at the crime scene, then the defendant is guilty.

$$
\begin{array}{llllllllll}
1 & 2 & 3 & 4 & 5 & 6 & 7 & 8 & 9 & 10
\end{array}
$$

20. DNA is the most accurate form of evidence. 


$\begin{array}{llllllllll}1 & 2 & 3 & 4 & 5 & 6 & 7 & 8 & 9 & 10\end{array}$




\section{Appendix E: Perceived Realism Scale}

21 . The crime you see on TV crime shows is very similar to crime in real life.

$\begin{array}{lllllll}-3 & -2 & -1 & 0 & 1 & 2 & 3\end{array}$

Not at all

Very True

True

22. TV crime programs show people what it is like to live in big cities.
$-3$
$-2$
$-1$
0
1
2
3

Not at all

Very True

True

23. Medical shows, like Grey's Anatomy and House, portray the same illnesses and emergencies that you see in real hospitals.
$-3$
$-2$
$-1 \quad 0$
1
2
3

Not at all

Very True

True

24. The doctors and nurses on medical shows handle medical emergencies just like real doctors and nurses.
$-3$
$-2$
$-1$
$0 \quad 1$
2
3
Not at all
Very True
True

25. If I were to go to a hospital, I would not expect it to be like the hospitals I see on television.

$\begin{array}{lllllll}-3 & -2 & -1 & 0 & 1 & 2 & 3\end{array}$

Not at all

Very True 
True

26. Television news informs me about what the world is really like.

$\begin{array}{lllllll}-3 & -2 & -1 & 0 & 1 & 2 & 3\end{array}$

Not at all

Very True

True

27. You can not learn much about the real world by watching television news.
$-3$
$-2$
$-1$
0
1
2
3

Not at all

Very True

True

28. I feel I can learn a lot about people from watching television news.
$-3$
$-2$
$-1$
0
1
2
3

Not at all

Very True

True

29. By watching television news, I can learn how to avoid some dangerous situations.

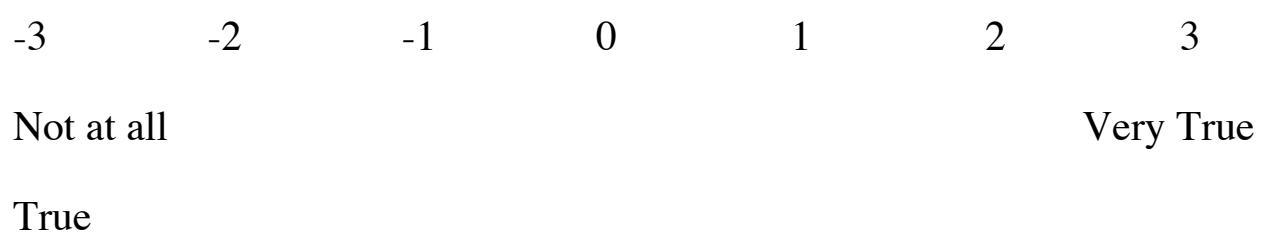

30. Characters in programs like Friends or How I Met Your Mother are very similar to people in the real world.
$-3$
$-2$
$-1$
0
1
2
3 
Not at all

Very True

True

31. The romantic relationships portrayed in drama programs are not at all like romantic relationships in the real world.

$\begin{array}{lllllll}-3 & -2 & -1 & 0 & 1 & 2 & 3\end{array}$

Not at all

Very True

True

32. The personal problems characters have in programs like Friends or How I Met Your Mother are very similar to problems real people have.

$\begin{array}{lllllll}-3 & -2 & -1 & 0 & 1 & 2 & 3\end{array}$

Not at all Very True

True

33. The issues that come up in programs like Friends or How I Met Your Mother are very similar to issues in the real world.
$-3$
$-2$
$-1 \quad 0$
1
2
3

Not at all

Very True

True

34. You can not learn anything about real life by watching prime-time drama programs.

$\begin{array}{llllllll}-3 & -2 & -1 & 0 & 1 & 2 & 3\end{array}$

Not at all

Very True

True 